Volume 4, Issue 2 (Summer 2012)

\title{
Drawing $\rightarrow$ Underdrawing $\rightarrow$ Painting: Compositional Evolution in the Working Process of Joachim Beuckelaer
}

Margreet Wolters

Recommended Citation:

Margreet Wolters, "Drawing $\rightarrow$ Underdrawing $\rightarrow$ Painting: Compositional Evolution in the Working Process of Joachim Beuckelaer," JHNA 4:2 (Summer 2012), DOI:10.5092/jhna.2012.4.2.2 Available at https://jhna.org/articles/drawing-underdrawing-painting-compositional-evolution-working-process-joachim-beuckelaer/

Published by Historians of Netherlandish Art: https://hnanews.org/

Republication Guidelines: https://jhna.org/republication-guidelines/

Notes: This PDF is provided for reference purposes only and may not contain all the functionality or features of the original, online publication. This is a revised PDF that may contain different page numbers from the previous version. Use electronic searching to locate passages. This PDF provides paragraph numbers as well as page numbers for citation purposes.

ISSN: $1949-9833$ 


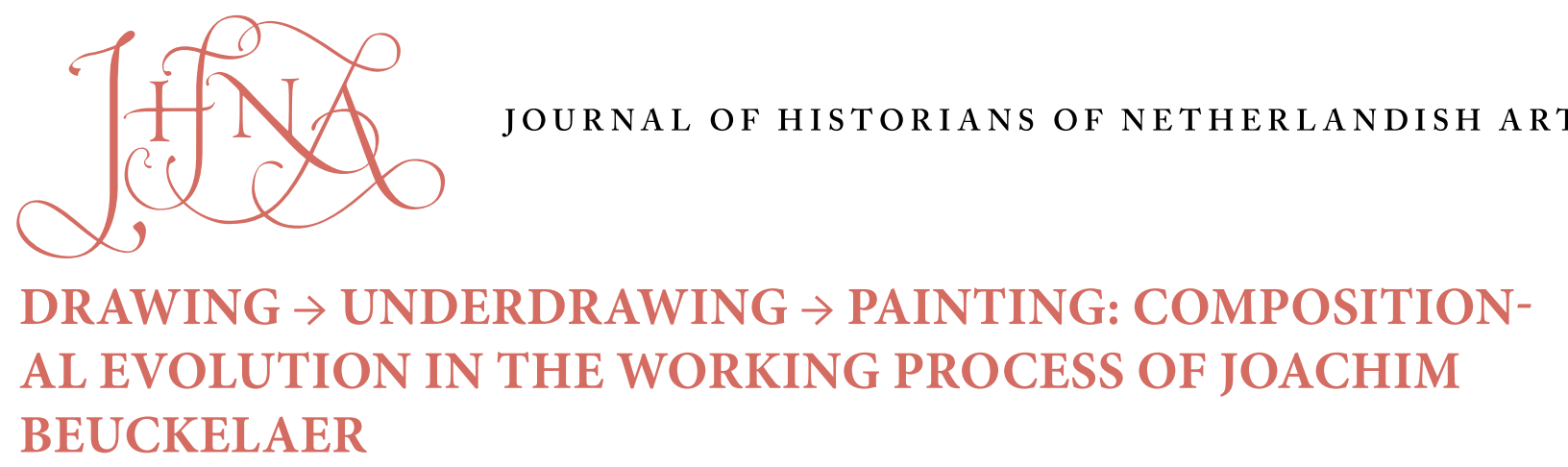

\section{Margreet Wolters}

This article compares a number of drawings and related paintings by the Antwerp artist Joachim Beuckelaer: three drawings of the Adoration of the Shepherds and two related painted versions of the same subject; two oil sketches on paper, each depicting half of a Crucifixion scene, and the associated painting; and a drawing and painting both representing Isaac Blessing Jacob. The paintings were examined with infrared reflectography (IRR), revealing for study the important intermediary step of the underdrawing. The article demonstrates how the artist began with a design on paper and worked toward the final paint stage in a continuous and supple design process that incorporated numerous shifts and changes in composition. It also shows that the use of squaring on drawings and paintings is not as straightforward as might be expected. Similarly, the deft handling of workshop models, as well as certain procedural idiosyncrasies, indicates that in most cases, instead of acting at the behest of his patrons, Beuckelaer himself was the one responsible for the changes. 10.5092/jhna.2012.4.2.2 esearch with infrared reflectography (IRR) has revealed that underdrawings in the paintings of Joachim Beuckelaer (Antwerp, ca. 1535-1575) often have a sketchy and spontaneous character. ${ }^{1}$ While this might indicate that the artist was working out the first ideas for his compositions directly on the support, this was certainly not always the case. ${ }^{2}$ In Beuckelaer's atelier there must have been a selection of drawings, sketches, studies, and models that were consulted during the painting process. ${ }^{3}$ Some of these shop drawings have in fact been preserved, ${ }^{4}$ and it is also known that Beuckelaer used other outside models during the creation of his works, such as compositions by his uncle and master Pieter Aertsen, ${ }^{5}$ the architectural books of Sebastiano Serlio and the Hypnerotomachia Poliphili. ${ }^{6}$ Still, the models that are known to us are probably only a portion, if not a tiny fraction, of what the artist assembled to support the production of paintings. ${ }^{7}$

Various sources report the use of such models in sixteenth-century workshops. An often-cited example is the legal case between Gerard David and Ambrosius Benson involving two trunks with working drawings and models for paintings and miniatures. The documents deriving from the lawsuit show how much importance was attached to this material. ${ }^{8}$ Similar items were also frequently listed in the inventories of painters' shops. ${ }^{9}$ Moreover, IRR research has brought to light ample evidence for the use of models. ${ }^{10}$ 
We know that Beuckelaer's master, Pieter Aertsen, used models in his shop. Not only did Van Mander mention that cartoons existed for twenty-five of Aertsen's altarpieces, ${ }^{11}$ Yvette Bruijnen's research has also shown that Aertsen reused the same partial cartoons for certain still-life motifs that repeated from one painting to another. ${ }^{12}$ Thus, Beuckelaer almost certainly became acquainted with the handling of models during his apprenticeship. ${ }^{13}$ Unfortunately, most of this working material has been lost over time. ${ }^{14}$

A number of Beuckelaer's surviving drawings can be related to paintings. There are three drawings and two paintings depicting the Adoration of the Shepherds (figs. 1-3, 11, 12); two oil sketches on paper, each with half of a Crucifixion scene, both related to a representation on panel (figs. 17a, 17b, 18); and a drawn sheet that can be linked to a painted composition with Isaac Blessing Jacob (figs. 25, 26). ${ }^{15}$ IRR has detected underdrawings in the paintings, revealing the essential step between the design on paper and the finalized work and elucidating how the drawings functioned as models. By setting up the comparisons discussed in this article, information can be obtained showing how these models were assimilated into the creative process. As will become apparent, it was typical of Beuckelaer to adapt and revise in each compositional stage as he worked toward the end result. Before beginning the analysis, however, it is necessary to provide a short introduction to Beuckelaer's drawings.

\section{Beuckelaer's Existing Drawings}

5 Tn the 1989 volume of Nederlands Kunsthistorisch Jaarboek, Wouter Kloek published a study 1 devoted to the drawings of Aertsen and Beuckelaer in which he assembled Beuckelaer's drawn oeuvre and noted important characteristics of the artist's works on paper. He determined that all of the drawings originated between 1560 and 1565/7, with most done in the first three years of the decade. Five of the fourteen sheets derive from 1562. Half of the drawings were designs for stained glass, both monumental as well as smaller windows. Two even included options for carrying out the window as either a round or a square shape. Kloek also described another completely new and significant aspect of Beuckelaer's studio practice: the making of oil sketches. Six sketches--a series of four sheets and the two loose Crucifixion halves--were executed with oil paint on paper. ${ }^{16}$ Kloek assumed that the four Old Testament sketches, with one in the series dated 1565, were intended as designs for prints. Furthermore, the author noted that squaring occurred on five of the drawings. ${ }^{17}$

6 Kloek's completely justified de-attribution of the Market Scene in the Lugt collection led to another important finding. ${ }^{18}$ With the exception of two sheets with possible historical subjects, ${ }^{19}$ all of Beuckelaer's drawings depict religious scenes. For a painter who is seen primarily as a specialist in market and kitchen scenes, ${ }^{20}$ this is not an insignificant observation and indicates that Beuckelaer was not working exclusively in this genre during the first half of the 1560 s.

\section{The Relationship between the Existing Drawings and Paintings}

\section{Adoration of the Shepherds}

7 The first instance of a drawing, which is associated with a painting, is the Adoration of the Shepherds, dated 1560, in the Metropolitan Museum of Art (fig. 1). ${ }^{21}$ This drawing is Joachim Beuckelaer's first known work, deriving from the same year during which the artist married and enrolled 
as a master in Antwerp's Guild of St. Luke. ${ }^{22}$ Beuckelaer's first paintings appear the following year and are dated $1561 .{ }^{23}$ Kloek suggested that the drawing may mark the development of a new prototype intended for later production. Although he attributed the drawing to Beuckelaer, he still assumed that it was executed in Aertsen's workshop. ${ }^{24}$ This new composition does indeed pay tribute to Aertsen's paintings of the same subject, such as the Adoration of the Shepherds in the Amsterdams Historisch Museum and the one in the Musée des Beaux-Arts, Rouen. ${ }^{25}$ Another drawing, which appeared on the market not so long ago and is now in the Teylers Museum in Haarlem, depicts the same subject and is stylistically related to the 1560 drawing; ${ }^{26}$ it represents a subsequent phase in the genesis of this composition (fig. 2). Since it seems to be a step farther in the direction of the final work, to be discussed below, ${ }^{27}$ it seems logical to assume this drawing was made following the one done in 1560. Since there are no indications for window subdivisions in either drawing, both must have been made as preparatory designs for painting.

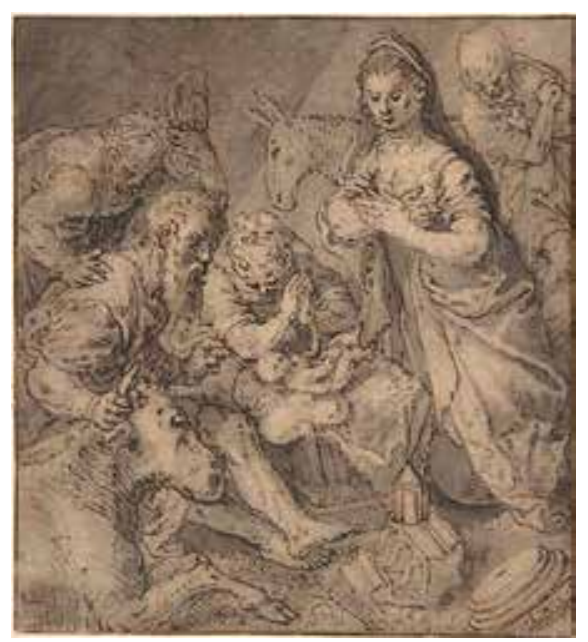

Fig. 1 Joachim Beuckelaer, Adoration of the Shepherds, dated 1560, pen in brown ink, with gray washes, squaring in red chalk, $175 \times 157$ $\mathrm{mm}$. New York, The Metropolitan Museum of Art (Bequest of Harry G. Sperling 1975), inv. no. 1975.131.137 (artwork in the public domain)

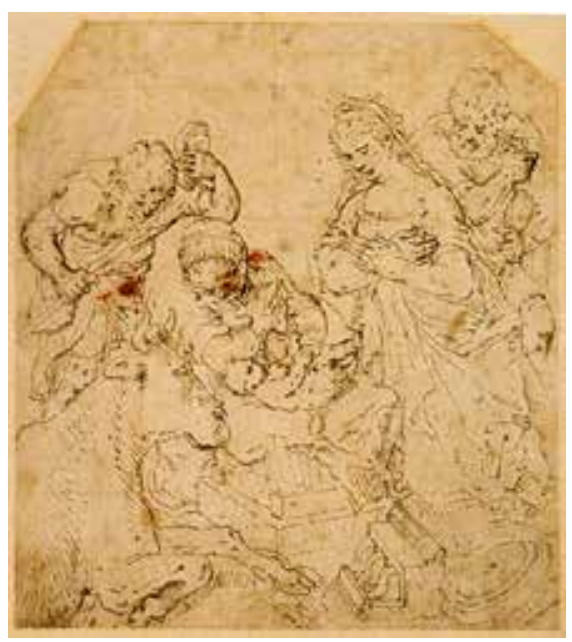

Fig. 2 Joachim Beuckelaer, Adoration of the Shepherds, pen in brown ink, squaring in red chalk, $180 \times 162 \mathrm{~mm}$. Haarlem, Teylers Museum (collection Matthijs de Clercq), inv. no. KT 2011:031 (artwork in the public domain)

In elucidating how Beuckelaer gradually worked toward the final composition, the two drawn versions must first be compared before determining their relationship to the version on panel. Both drawings show small changes. ${ }^{28}$ Most are slight revisions, such as the adjustment of Mary's headdress in the 1560 drawing or the ox's hoof in the second sketch. ${ }^{29}$ The way the artist adapted the composition in the second drawing relative to the first one is indicative of his approach. The composition is made more compact overall, and the figures are pulled closer together. The seated shepherd on the left side and the donkey in the background have both been omitted. The standing shepherd's position has been adapted to the new situation, and he now holds a shepherd's crook in his right hand. Leaning forward with her head bent, Mary appears more focused on the Christ child. The lantern, placed below on the fragment of a column base in the first drawing, is held by Joseph in the later drawing. ${ }^{30}$ oration of the Shepherds in the church of St. Ursula in Cologne (fig. 3) ${ }^{31}$ It appears, however, that once the drawings were done, the creative process was far from finished, since further changes 


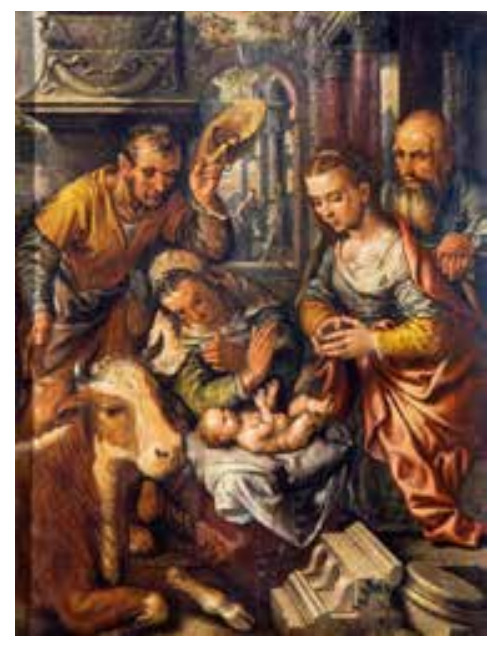

Fig. 3 Joachim Beuckelaer, Adoration of the Shepherds, dated 1565, panel, $141 \times 107 \mathrm{~cm}$. Cologne, church of St. Ursula (artwork in the public domain)

can be observed in the painted surface. The figural group has become even more compact, and the background has been given form by the addition of classical architecture reminiscent of Sebastiano Serlio. The column base with eagles in the upper left is a direct borrowing from Serlio's Book III. ${ }^{32}$ Adjustments have been made in all of the foreground figures. Compared with the drawings, Mary's crossed hands and the shepherdess's folded hands have been exchanged. ${ }^{33}$ The Christ child's arms and legs have been altered. The fold pattern is more complex in the cloth wrapped around the cushion under the Christ child, and the original wooden crib has been transformed into a large, stone block. The shepherd on the left no longer carries a crook but holds his right hand open, while making an elegant gesture with his other hand and holding a much larger hat. The ox in the foreground now glances out to the viewer rather than looking in the direction of the Christ child. ${ }^{34}$ Finally, the date--1565--has been added on the column base that is angled downward in the lower right corner, ${ }^{35}$ just as in the drawing from 1560.

IRR research of the St. Ursula painting reveals that a number of the modifications that had been made relative to the drawings were already present in the layout stage. ${ }^{36}$ This is not true, however, of all of the changes. ${ }^{37}$ Given the fact that both drawings have been squared with red chalk, perhaps the artist originally intended to transfer the composition of the drawing directly to the panel. ${ }^{38}$ Yet this plan must have been abandoned even before the underdrawing was begun, because there is no squaring to be seen on the panel, either with the unaided eye or with IRR. ${ }^{39}$

11 Although the exchanged hands of Mary and the shepherdess were included in the underdrawn layout, many other alterations and modifications occurred during the painting process. ${ }^{40}$ In several instances these changes were made as the composition was being worked out in paint, since in the underdrawing stage they correspond to the preparatory sketch. It can be seen with IRR--and also partially with the naked eye--that a bent arm and hand holding a crook were underdrawn under the shepherd's arm that is currently visible, stretching out below to his open hand (fig. 4). This exactly matches the detail in the second drawing. ${ }^{41}$ The bent arm was not only underdrawn in black chalk, ${ }^{42}$ it was also taken (at least in part) into the paint stage since (dark) portions of the arm and crook are visible underneath the present sleeve. The first position was apparently unsatisfactory, and it was decided during the painting process to give the arm its present form, perhaps to better close off the composition on the left side. This is an excellent illustration of the ongoing 
creative process that is typical of Joachim Beuckelaer's manner of working.

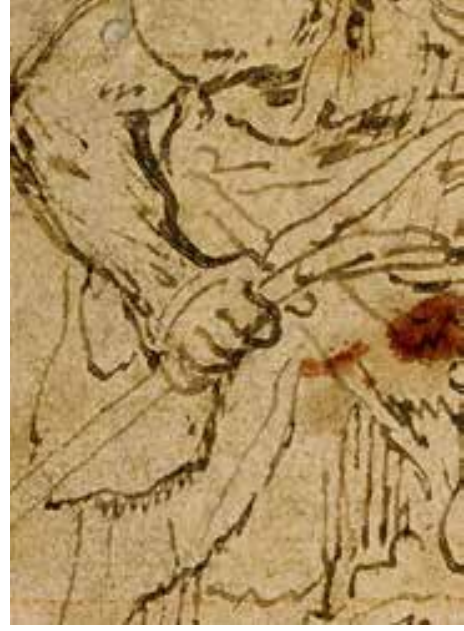

Fig. 4a Joachim Beuckelaer, Adoration of the Shepherds, Haarlem (fig 2). Detail of the right arm and hand of the shepherd on the left.

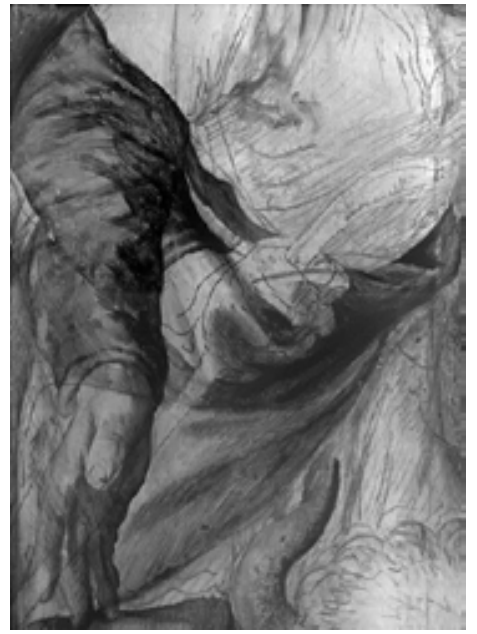

Fig. $4 \mathrm{~b}$ Joachim Beuckelaer, Adoration of the Shepherds, Cologne (fig. 3). IRR digital composite of the right arm and hand of the shepherd on the left, @ RKD, The Hague

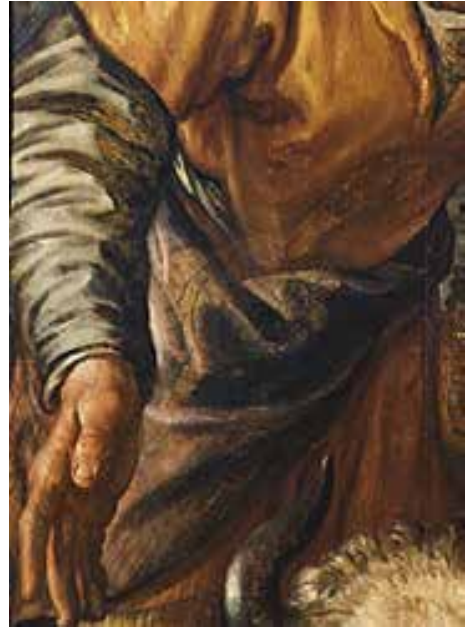

Fig. 4c Joachim Beuckelaer, Adoration of the Shepherds, Cologne (fig. 3). Detail of the right arm and hand of the shepherd on the left.

12 A similar change occurs in the hand and hat of the same shepherd. The underdrawing did not predict the final form here either. The IRR composite shows that the hat was underdrawn much smaller, more closely matching the drawing (fig. 5). Only after the architecture was (almost) completely finished was it decided to enlarge the hat with a rim and rounded top.

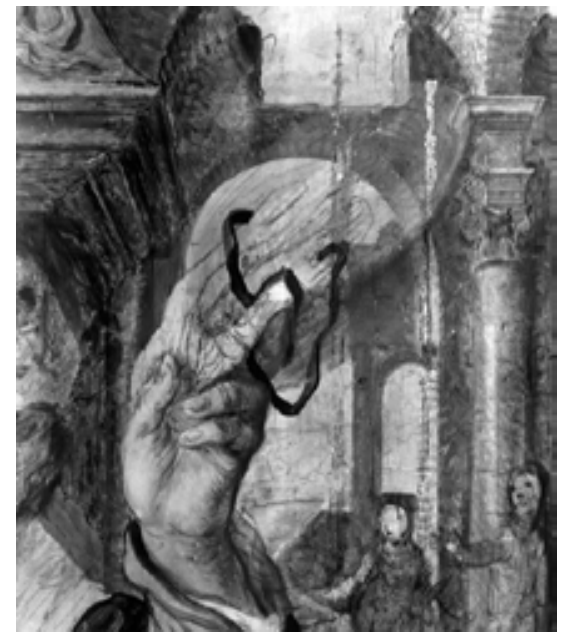

Fig. 5 Joachim Beuckelaer, Adoration of the Shepherds, Cologne (fig. 3). IRR digital composite of the hat of the shepherd on the left, ( RKD, The Hague

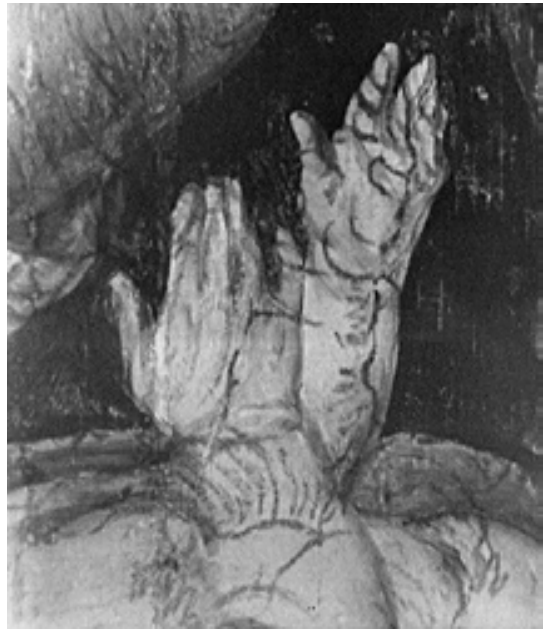

Fig. 6 Joachim Beuckelaer, Adoration of the Shepherds, Cologne (fig. 3). IRR digital composite of the Christ child's arms, @ RKD, The Hague

13 The IRR research shows that, compared with the drawn sheets, this searching for the most satisfying form also occurs elsewhere in the composition. In the figure of the Christ child, the furthest arm has been drawn under the arm that is now the nearest (fig. 6). The underdrawn arm is thus closer to that in the two drawings. 
14 The underdrawing is difficult to interpret in the stone block on which the Christ child lies. While both drawings include a wooden crib, a stone block has been depicted in the paint surface. The underdrawing under the fabric hanging from the cushion shows several short, straight lines as well as some forms that are rounded on the bottom (fig. 7). These are suggestive of the slats of the crib, as they appear in the drawings. It is possible that the crib was still planned during the underdrawing stage and then, during a later creative phase, was replaced by the stone block. Choosing to add the cushion and cloth had already taken place before the underdrawing was begun. Nonetheless, other modifications were still introduced as the image was worked out in paint.

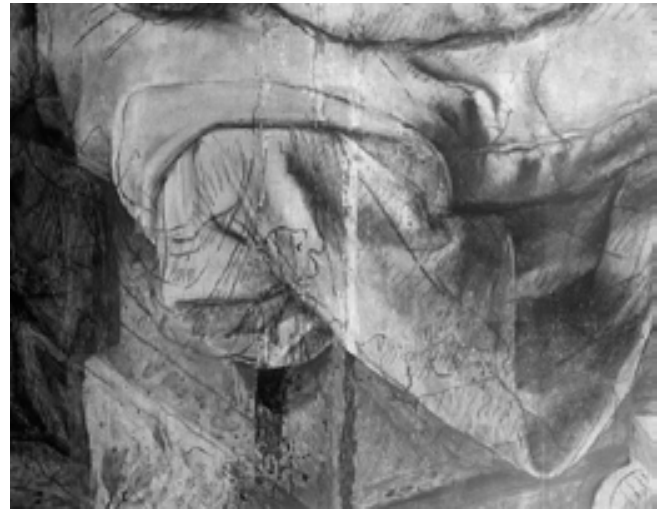

Fig. 7 Joachim Beuckelaer, Adoration of the

Shepherds, Cologne (fig. 3). IRR digital composite of the Christ child's crib, (C RKD, The Hague

The analysis of the IRR images reveals that as compared with the previous design the artist began to make some changes as soon as the underdrawing was being laid out. In those areas, however, where the painter continued to follow the drawn model on paper, he then deviated strongly from the underdrawn layout during the next working phases. Sometimes this occurred while the underdrawing was being executed, as in the crib, or sometimes in a later stage during the application of the paint layers.

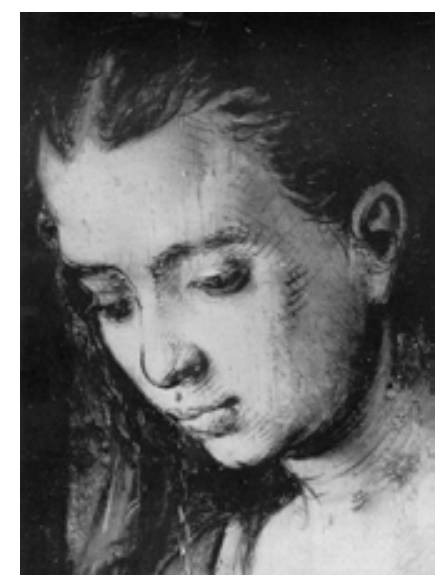

Fig. 8 Joachim Beuckelaer, Adoration of the Shepherds, Cologne (fig. 3). Infrared photograph of the head of Mary

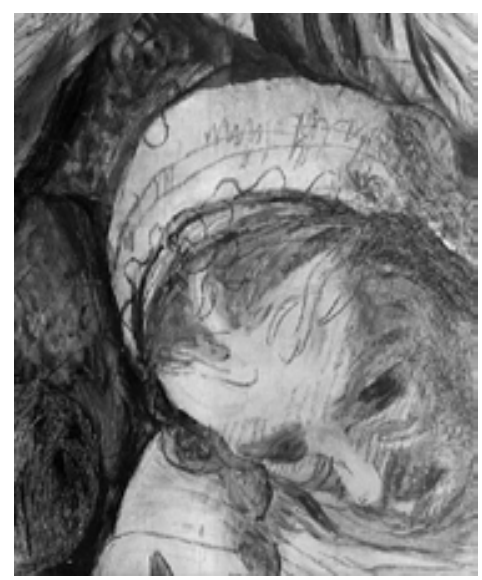

Fig. 9 Joachim Beuckelaer, Adoration of the Shepherds, Cologne (fig. 3). IRR digital composite of the head of the shepherdess, (c) RKD, The Hague

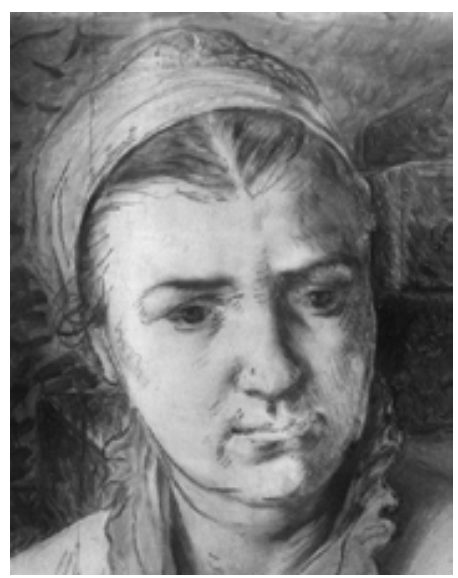

Fig. 10 Joachim Beuckelaer, Two Market Women, dated 1561, panel, $124.5 \times 92.7 \mathrm{~cm}$. Vienna, Kunsthistorisches Museum, inv. no. 3559. IRR digital composite of the head of the woman on the right, @ RKD, The Hague

Another distinct feature of the underdrawing is the density of hatching, especially in the heads of Mary and the shepherdess (figs. 8 and 9). ${ }^{43}$ Beuckelaer's underdrawings from around 1565, the date of the painting, generally exhibit less worked out modeling in the shadow areas (see figs. 13, 
14). In this respect the underdrawing of the Adoration is not only closer to the two drawings but also to underdrawings in earlier paintings by Beuckelaer, such as the Two Market Women in Vienna (fig. 10) or the Market Scene with Ecce Homo in Stockholm, both dated $1561 .{ }^{44}$ This suggests that the underdrawing was executed earlier than 1565, the date on the painting. The work may have stood for a while in the studio before it was finished and the date added. ${ }^{45}$

17 It is not impossible that the St. Ursula painting functioned as a model in the shop for a certain period of time. There are, in fact, a number of almost identical replicas of this composition. ${ }^{46}$ What is especially notable is that these copies--which show some slight differences--are dated 1561 to $1562 .{ }^{47}$ If the Ursula work was available for a period in the shop, that could explain the early dates of these versions. It is also possible, however, that these are later copies which have been incorrectly dated too early. ${ }^{48}$ None of these works has been examined by IRR, but since without exception they all repeat the painted surface of the St. Ursula painting, the work in Cologne must have been the basis of these examples.

18 Another Adoration of the Shepherds, dated 1565 as well, but also provided with Beuckelaer's monogram, is in the church in Court-Saint-Etienne (fig. 11). ${ }^{49}$ The evolving composition has been revised by combining and manipulating elements from the painting in Cologne as well as the two earlier drawings. Also playing a role in this process are components of another work on paper, a design for a monumental stained-glass window with the Adoration of the Shepherds in the Kunsthalle, Hamburg, dated 1563 (fig. 12). ${ }^{50}$

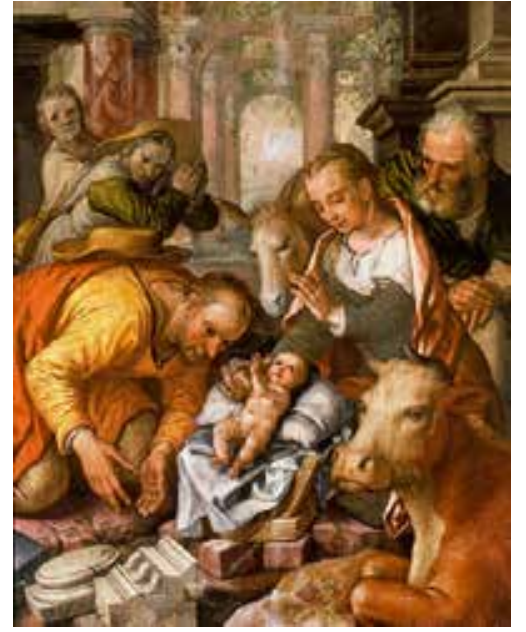

Fig. 11 Joachim Beuckelaer, Adoration of the Shepherds, monogrammed and dated 1565 , panel, $140 \times 110 \mathrm{~cm}$. Court-Saint-Etienne (Belgium), church of St. Etienne (artwork in the public domain) Photo: Peter van den Brink

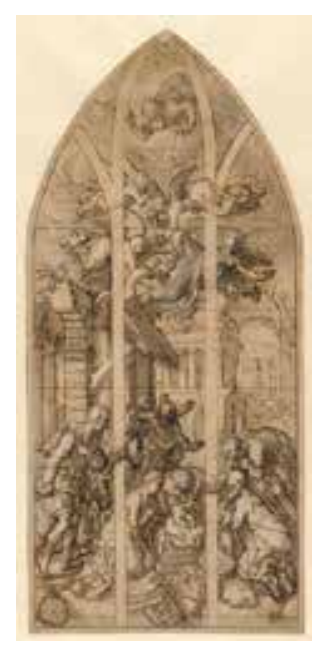

Fig. 12 Joachim Beuckelaer, Adoration of the Shepherds, dated 1563, pen in brown ink, with brown washes, traces of squaring, $400 \times 190 \mathrm{~mm}$. Hamburg, Hamburger Kunsthalle, inv. no. 21626 (artwork in the public domain)

19 Mary and Joseph are still positioned on the right side of the scene, as they appear in the compositions discussed above. Their postures, however, have been altered, and Mary now tenderly holds the Christ child's right arm. The child is foreshortened and placed on a diagonal, as in the Hamburg drawing, and in contrast to the profile presentation in the two other drawings and the panel in Cologne. In the Court-Saint-Etienne panel, the positions of the child and Mary are the reverse of the figures in the Hamburg sheet. Whereas in Cologne the artist opted for a stone block, the Christ child now lies in a wooden crib as in the three drawn versions. 
20 The adjustments in the shepherd in the left foreground are more radical. This figure is now shown nearly full length, because the ox and antique fragments have changed places. Beuckelaer seems to have created this form by combining, in reverse, the kneeling figure in the foreground of the Hamburg drawing--perhaps Joseph--with the sharply bent figure just behind. ${ }^{51}$ In addition, two more shepherds have been added in the left background of the painting.

21 The underdrawing in the painting at Court-Saint-Etienne differs considerably from that in the St. Ursula panel. ${ }^{52}$ In contrast to the work in Cologne, it is less heavily shaded, and as such, more closely related to works by Beuckelaer that date around 1565 . This can be seen in the comparison of the head of Mary with that of the Vegetable Seller in Kassel (figs. 13 and 14). ${ }^{53}$

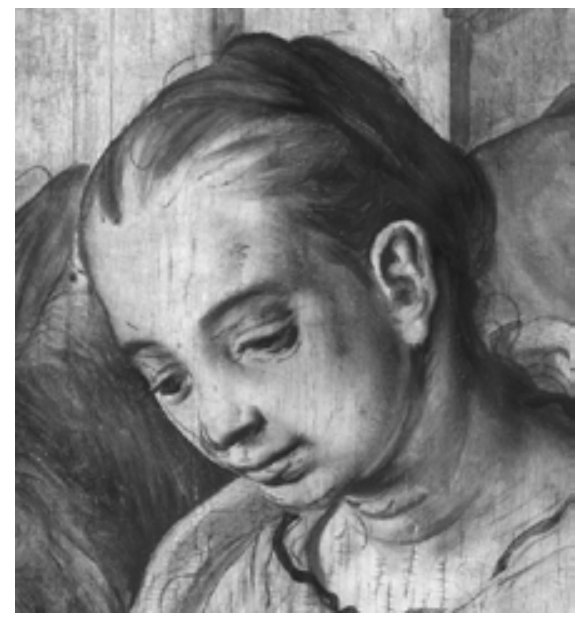

Fig. 13 Joachim Beuckelaer, Adoration of the Shepherds, Court-Saint-Etienne (fig. 11). IRR digital composite of the head of Mary, @ KIK-IRPA, Brussels

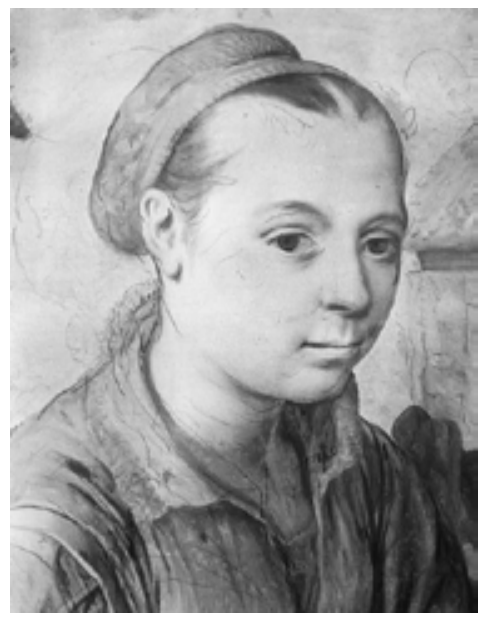

Fig. 14 Joachim Beuckelaer, Vegetable Seller, dated 1564, panel, $114.8 \times 170.5 \mathrm{~cm}$. Kassel, Staatliche Museen, Gemäldegalerie Alte Meister, inv. no. GK 41. IRR digital composite of the woman's head, @ RKD, The Hague

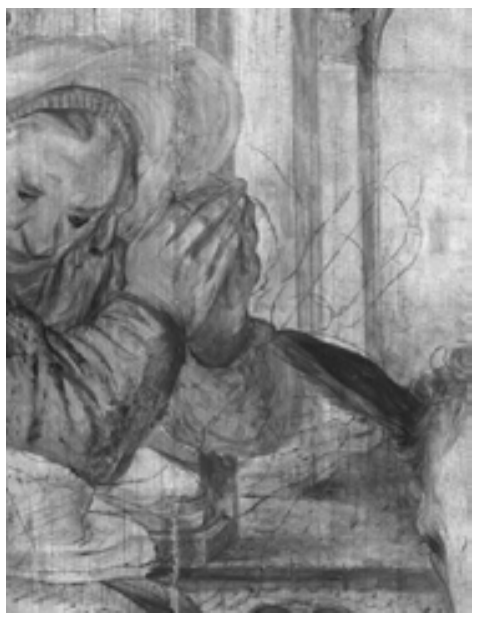

Fig. 15 Joachim Beuckelaer, Adoration of the Shepherds, Court-Saint-Etienne (fig. 11). IRR digital composite of the old shepherdess, @ KIK-IRPA, Brussels

In the Court-Saint-Etienne work, there are fewer modifications relative to the underdrawing, perhaps indicating that the composition was already established to a greater degree before the underdrawing was begun than was the case in the Cologne painting. The most obvious change appears in the shepherdess on the left (fig. 15). In the underdrawing her hands were larger and longer, and her head was bent forward more. The lines visible just above the underdrawn hands may indicate that the shepherdess was intended to hold some sort of object. During work on the panel, the painter continued to search for this figure's final form.

23 There are in addition a number of small alterations that are more rightly regarded as corrections than radical compositional changes. It is typical of Beuckelaer that he would underdraw a short sleeve, such as that on the right arm of the shepherd in the foreground, and then finish it in paint as a long sleeve (fig. 16). Other slight modifications occurred during the application of the paint layers, such as in the cloth around Mary's shoulders and in her hairdo, which was extended on the top. ${ }^{54}$ There is thus also evidence in this painting for ongoing change as the image was finalized, even though to a lesser degree than in the painting discussed earlier. It would not be surprising to 
find that the panel at Court-Saint-Etienne was preceded by a variant that closely resembled this composition. ${ }^{55}$

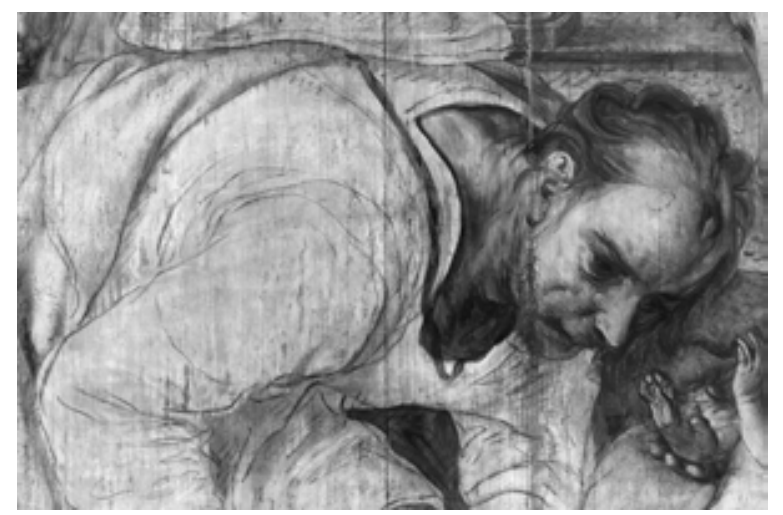

Fig. 16 Joachim Beuckelaer, Adoration of the Shepherds, Court-Saint-Etienne (fig. 11). IRR digital composite of the shepherd's sleeve, @ KIK-IRPA, Brussels

\section{The Crucifixion}

24 Two oil sketches on paper in the Louvre--designs for stained-glass windows--provide the basis for another analysis. Each sheet depicts half of a Crucifixion scene (figs. 17a and 17b) ${ }^{56}$ and may be compared to a painted Crucifixion (also in the Louvre), where the two halves have been united into one composition (fig. 18). ${ }^{57}$ Both the painting and the oil sketches have been examined by IRR, yielding not only a comparison between the underdrawing and the two sketches in their final form but also between the underdrawing and the final result in the painting. This gives good insight into Beuckelaer's working method, which in this case is surprisingly dynamic.

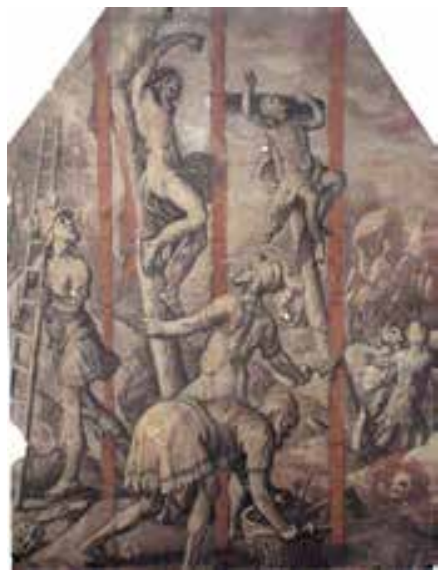

Fig. 17a Joachim Beuckelaer, left half of a Crucifixion with the two thieves, oil paint on reddish-brown prepared paper, $312 \times 236 \mathrm{~mm}$ (with angled upper corners). Paris, Musée du Louvre, Département des Art Graphiques, inv. no. 20701 (artwork in the public domain) Photo: @ Musée du Louvre / Micha Leeflang

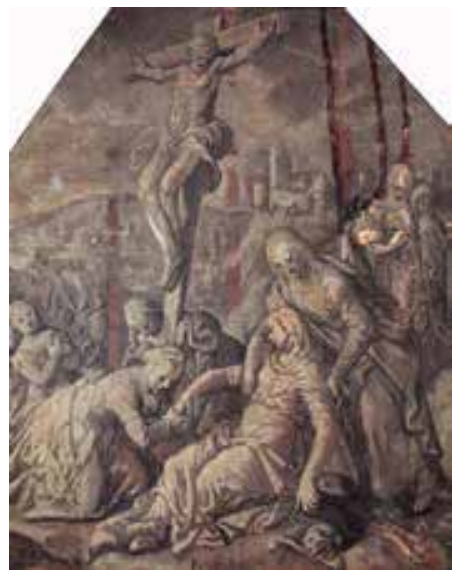

Fig. 17b Joachim Beuckelaer, right half of a Crucifixion with the crucified Christ, monogrammed, oil paint on reddish-brown prepared paper, $308 \times 242$ $\mathrm{mm}$ (with angled upper corners). Paris, Musée du Louvre, Département des Art Graphiques, inv. no. 20709 (artwork in the public domain) Photo: @ Musée du Louvre / Micha Leeflang

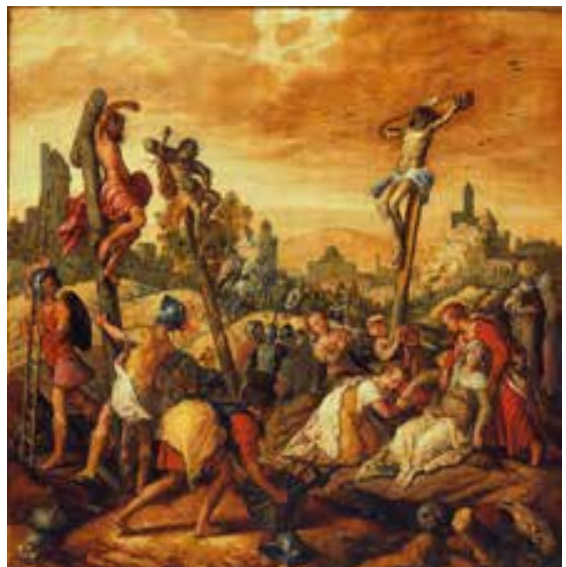

Fig. 18 Joachim Beuckelaer, Crucifixion, monogrammed and dated 1567, panel, $56.5 \times 56 \mathrm{~cm}$. Paris, Musée du Louvre, inv. no. RF 1997-6 (artwork in the public domain)

25 Although at first glance it seems that the sketches have simply been joined together in the painting, this is clearly not the case, since the combination has resulted in a number of compositional 
shifts. Although a narrow strip may be missing along the bottom edge of the sketches, ${ }^{58}$ this cannot entirely explain the expansiveness of the scene on panel. A greater sense of depth has been achieved by the larger amount of space above and below the figures. The composition has also become a tall rectangle, in contrast to the much wider format of the two sketches. The bending man with the basket in the foreground has been moved to the right, as the two halves have been merged and newly created hills establish a link between the distant landscape and the foreground. The composition has been heightened by raising the crucified figures high on their crosses, where they are silhouetted above the people on the ground. This probably necessitated lifting the buildings on the right and creating completely new ones on the left.

26 Over and above these compositional interventions, all sorts of modifications occur in the figures. The positions of the Virgin Mary's and John's heads have been shifted in a way comparable to the exchange of hands between Mary and the old shepherdess in the Cologne Adoration of the Magi. And there are changes in the heads and arms of the two thieves. In a very free way, the artist has made creative leaps away from the sketches.

27 IRR was able to detect underdrawings in both sketches on paper as well as in the panel, all executed in a dry material. ${ }^{59}$ In the sketches, summary indications appear in the form of contour lines (figs. 19a-b), while the panel exhibits a more thoroughgoing preparation that includes hatching (figs. 20, 21c, 22-24). Squaring, done at a very reduced scale given the size of the work, has also been detected in the panel (fig. 20). ${ }^{60}$ Despite the fact that a grid pattern occurs on a number of

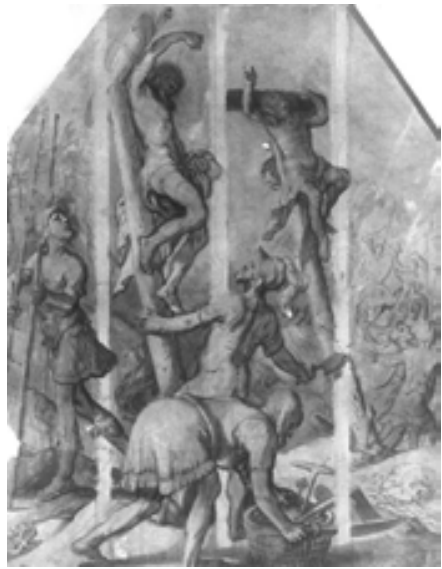

Fig. 19a Joachim Beuckelaer, left half of a Crucifixion with the two thieves, Paris (fig. 17a). IRR digital composite, @ RKD, The Hague

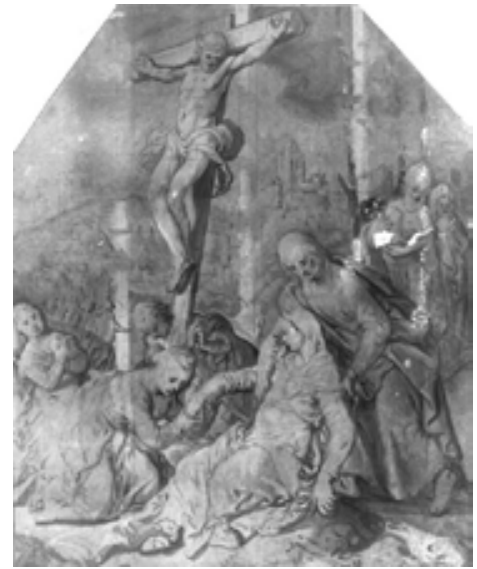

Fig. 19b Joachim Beuckelaer, right half of a Crucifixion with the crucified Christ, Paris (fig. 17b). IRR digital composite, ( ) RKD, The Hague

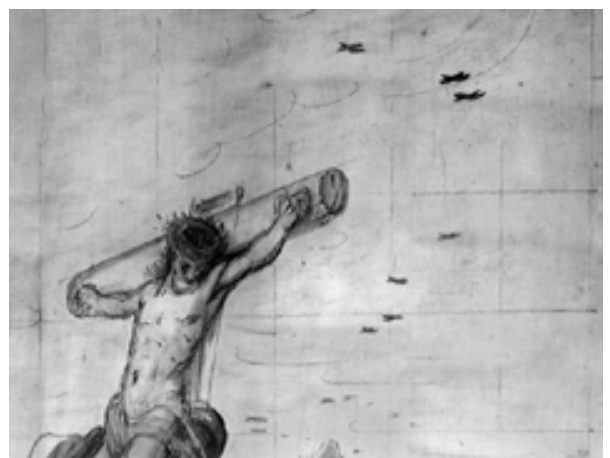

Fig. 20 Joachim Beuckelaer, Crucifixion, Paris (fig. 18). IRR digital composite showing the squaring, (C RKD, The Hague

Beuckelaer's drawings, it is lacking in the oil sketches and cannot be seen with either the unaided eye or IRR. This raises the question of what the precise relationship was between the sketches and the painting. Perhaps Beuckelaer created another design that formed a link between the sketches and the painting in the Louvre, ${ }^{61}$ and it was this intervening version that was squared. Still, it is curious that the underdrawing appears so loose and sketchy, with frequent changes between it and the paint stage, when squaring is normally used to transfer a composition that has been fully worked out in all its details. Another possibility is that the compositions of the oil sketches were 
transferred freehand to the panel, and that they were squared only afterwards. In this case, the composition established in the underdrawing would be used for any further repetitions. ${ }^{62}$ Which of the two possibilities is correct cannot be determined with the material available at present.

Based on the layout in the underdrawing of the united composition, it can be established with certainty that the two oil sketches preceded the painting on panel. There are forms visible in the underdrawing that match those in the sketch, but they have been altered in the paint stage. This can be seen in the figure with the basket of tools (figs. 21 b-d). His costume was underdrawn following the sketch: there is a fold line between the legs, and the double layer of fabric has a striped pattern underneath. In paint, the artist has arrived at a completely different form, with a pointed piece of cloth hanging over the skirt underneath. This shape was added on the already-painted background, indicating that changes were still being introduced during the painting process. As in the sketch, the upper torso of this figure is also longer in the underdrawing, with arms and head positioned farther to the right. Comparison with the first version of this figure, drawn in chalk in the oil sketch, gives further insight into Beuckelaer's working process, since changes also occur in the sketches relative to the underdrawing stage. Chalk lines in this figure's left foot show that it was placed flatter on the ground, while in the paint stage of the oil sketch, the heel is higher, and in the painted version on panel, the man stands even more on his forefoot. The gradual development of this motif suggests that the man's movement was meant to imply he was packing up his basket in order to leave the scene.

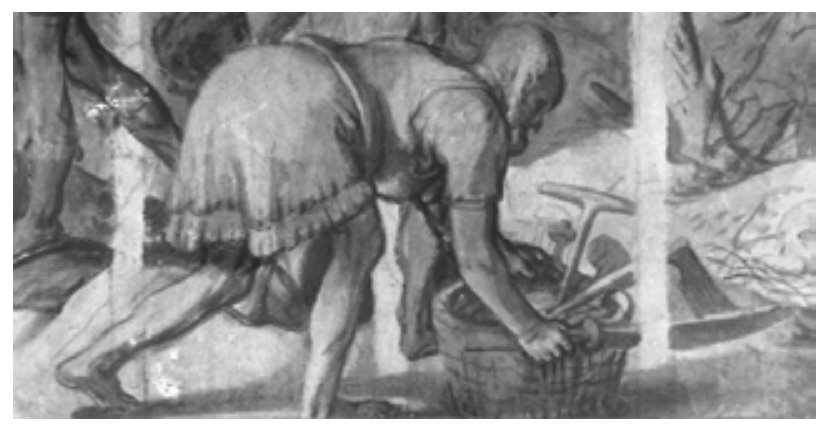

Fig. 21a Joachim Beuckelaer, left half of a Crucifixion with the two thieves, Paris (fig. 17a). IRR digital composite of the figure with a basket holding tools, @ RKD, The Hague

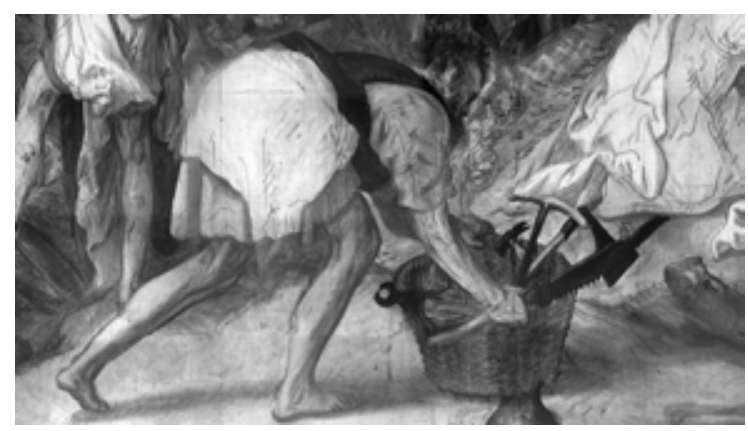

Fig. 21c Joachim Beuckelaer, Crucifixion, Paris (fig. 18). IRR digital composite of the figure with a basket holding tools, @ RKD, The Hague

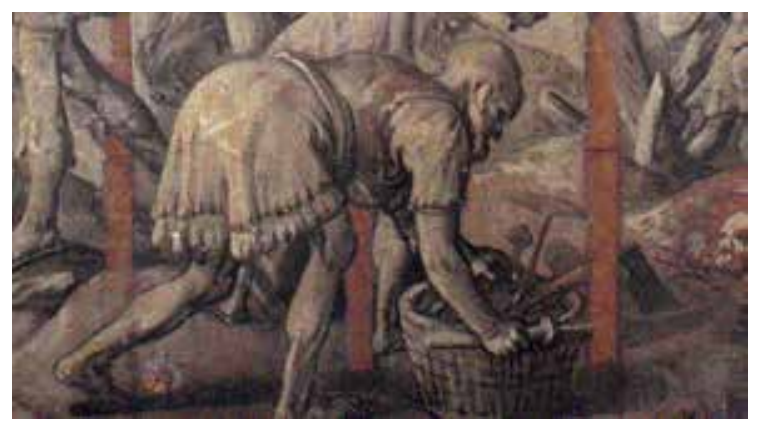

Fig. 21b Joachim Beuckelaer, left half of a Crucifixion with the two thieves, Paris (fig. 17a). Detail of the figure with a basket holding tools

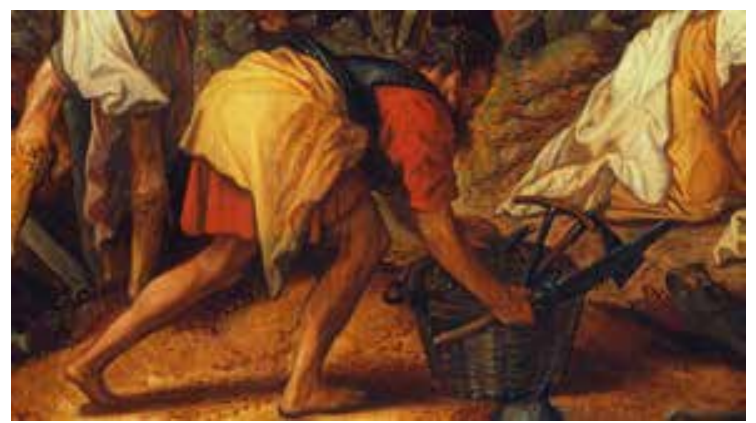

Fig. 21d Joachim Beuckelaer, Crucifixion, Paris (fig. 18). Detail of the figure with a basket holding tools 
In the underdrawing on the panel, the heads of the two thieves are closer to the oil sketch as well (fig. 22). In the sketch, the good thief, who is on the right, looks up to heaven, while the thief on the left looks down. In the painting this figure looks toward his fellow-sufferer, although the underdrawing shows that his head was originally tilted down, just as in the sketch. ${ }^{63}$ The positions of the Virgin Mary's and John's heads were exchanged even before the underdrawing had been laid out, while other revisions, as in the costumes of the figures under the cross, correspond again to the oil sketch (fig. 23). In the leg of the kneeling Mary closest to the foreground, chalk lines can be observed defining a strip of cloth as it appears in the sketch. A line is visible in her right arm that matches the short sleeve seen in the oil sketch. All of these forms, however, were adjusted in the final paint surface.

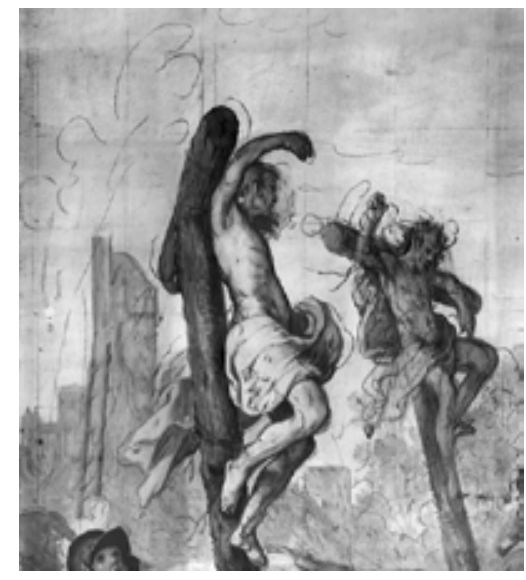

Fig. 22 Joachim Beuckelaer, Crucifixion, Paris (fig. 18). IRR digital composite of the two thieves, (C) RKD, The Hague

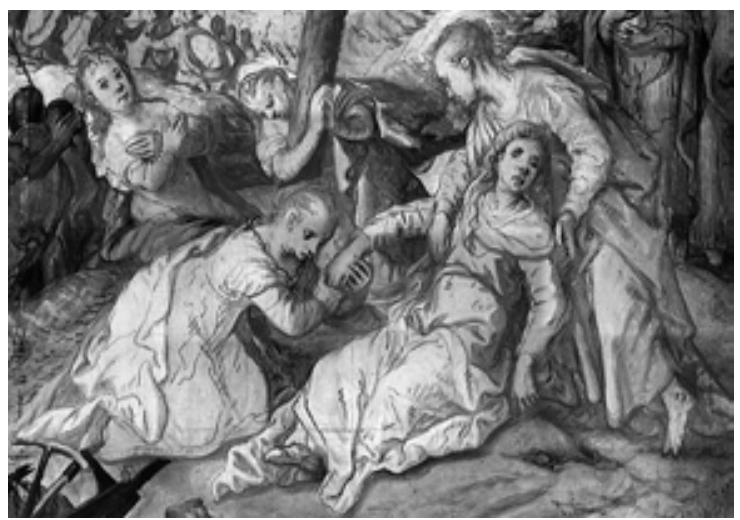

Fig. 23 Joachim Beuckelaer, Crucifixion, Paris (fig. 18). IRR digital composite of the figures under the cross on the right, @ RKD, The Hague

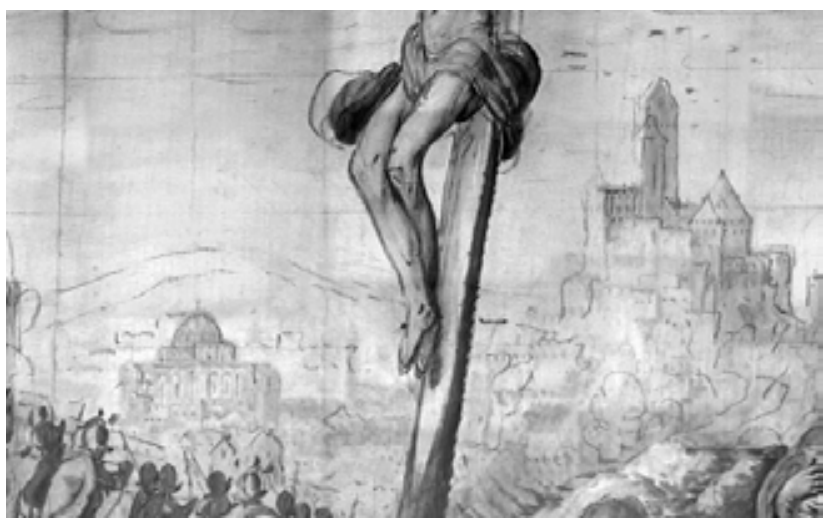

Fig. 24 Joachim Beuckelaer, Crucifixion, Paris (fig. 18). IRR digital composite of the architecture, $\odot$ RKD, The Hague

The architecture shows changes as well (fig. 24). The towers on the right side were underdrawn lower, which might be indicative of the fact that, as compared with the sketches, the height of these motifs had to be adjusted. It is noteworthy that the higher positions of the towers were also underdrawn, proving that the modification had already taken place during the layout phase.

31 Although it is clear that the oil sketches and the panel are closely related, the presence of squaring on the panel makes it impossible to define what the exact relationship between them might have been. The oil sketches clearly came before the panel, and once again, Beuckelaer remained closer 
to his models in the underdrawing, while making deviations during the painting process. The modifications and adjustments of form are constant, not only in relation to the model on paper, but also in the underdrawing stage, and during the application of the paint layers. Changes are introduced at every phase of the working process that are creative and exhibit a distinct personal character. This leads to the strong impression that Beuckelaer carried out this process without the help of assistants.

32 It is remarkable that a Crucifixion design in two halves, probably intended for a specific location with two windows, could be merged into one painted composition. ${ }^{64}$ The process resulted in an unusual asymmetrical Crucifixion scene, with the two thieves on the left and the crucified Christ on the right. ${ }^{65}$

\section{Isaac Blessing Jacob}

33 The last case study concerns a single sheet, a drawing dated 1561 and preserved in the Herzog Anton Ulrich-Museum in Braunschweig (fig. 25). It depicts Isaac Blessing Jacob (Genesis 27, $1-31)^{66}$ and relates to a panel of the same subject in the Museum Catharijneconvent, Utrecht, with the date 1568 (fig. 26) ${ }^{67}$ Compared with the representation on paper, the painting exhibits so many radical changes ${ }^{68}$ that an intervening drawing or painting cannot be ruled out. Nonetheless, by comparing the drawing in Braunschweig, the underdrawing, and the painted surface of the Utrecht work, it can be shown that the working procedure is entirely in keeping with Beuckelaer's overall approach, as described above.

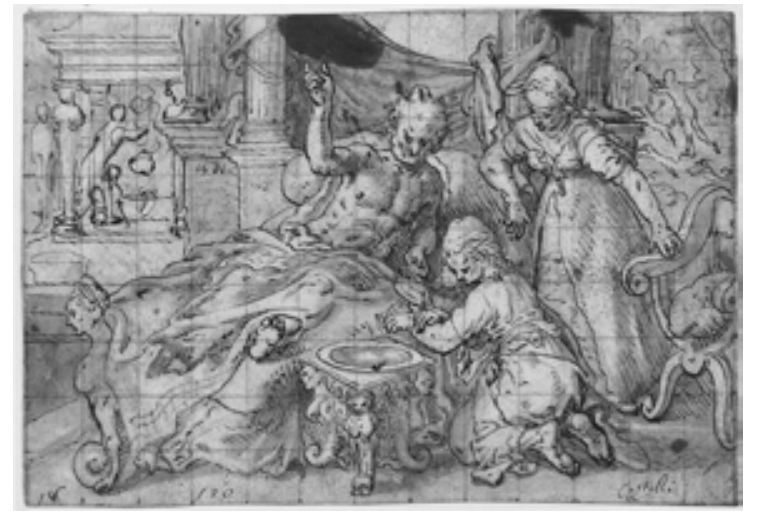

Fig. 25 Joachim Beuckelaer, Isaac Blessing Jacob, dated 1561, pen in gray ink, with gray washes, squaring in red chalk, $168 \times 243 \mathrm{~mm}$. Braunschweig, Herzog Anton Ulrich-Museum, inv. no. Z 1147 (artwork in the public domain)

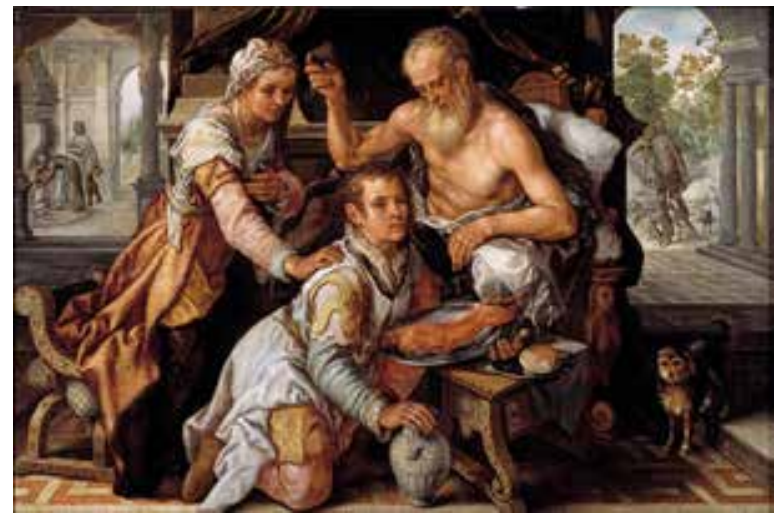

Fig. 26 Joachim Beuckelaer, Isaac Blessing Jacob, monogrammed and dated 1568, panel, $112.3 \times 170.8 \mathrm{~cm}$. Utrecht, Museum Catharijneconvent, inv. no. BMH s76 (artwork in the public domain) Photo: (C) Museum Catharijneconvent, Utrecht / Ruben de Heer

34 Rebecca and Jacob are depicted to the right of Isaac in the drawing. In the painting, however, they have been reversed, shifted to the left of the blind patriarch, and altered somewhat in posture. The repositioning of Rebecca and Jacob required Beuckelaer to foreshorten the upper torso of the elderly man and adjust the direction of his glance. He also made the lower half of Isaac's body much less noticeable. Thus, the main figural group has been made more compact in the Utrecht painting--a compositional manipulation that has been signaled elsewhere in Beuckelaer's working procedure. 
Another feature of the painted version is a change in iconography. In the drawing Jacob is seen from the back, ${ }^{69}$ but in the painting he is depicted more from the front. This revision brings the goat's hide into view, which had been placed by Rebecca around her son's neck in order to deceive Isaac into thinking that Jacob was actually his older brother Esau, who was more hairy. Although the biblical account mentions that the hide also covered the hands, all we see in the painting is a fur cuff around Jacob's right wrist. With his other hand, the deceiving son holds a platter containing the goat, now prepared as a meal, a motif that is lacking in the drawing. This makes it evident that Jacob is the one offering the meal to his father, as is further suggested by the placement of his other hand on the jug of wine. Rebecca's role as initiator of the intrigue is implied by the hand she presses on her youngest son's shoulder, a position quite different from her more neutral stance in the drawing. Shifting the figural group to the left caused the background vignette on the right to be given greater emphasis. Here Esau is depicted frontally rather than from the back, and, from the trophy he holds, it is apparent that he is returning from the hunt rather than departing. This is a more logical moment to depict, since it was shortly after the blessing that Esau returned from the hunt to discover the deception. Changes also occur in the background vignette on the left, where the meal is being prepared for Isaac. The Corinthian fireplace, which has been taken from Sebastiano Serlio, has been transformed into a Doric one. ${ }^{70}$ As is usual with Beuckelaer, the fireplace has been foreshortened in the painting while, in Serlio, the motif is seen straight-on. ${ }^{71}$

36 The drawing has been squared in red chalk, but the painted representation deviates so sharply from the drawing that it is impossible to assume the grid could have been used to transfer the composition. And indeed, no squaring could be detected in the panel, either with IRR or with the naked eye. ${ }^{72}$ The underdrawing does show--once again--that the composition was not fixed in the layout stage and that a number of underdrawn motifs are closer to the drawing on paper. ${ }^{73}$ It again becomes apparent that Beuckelaer was gradually working toward the final manifestation of the image.

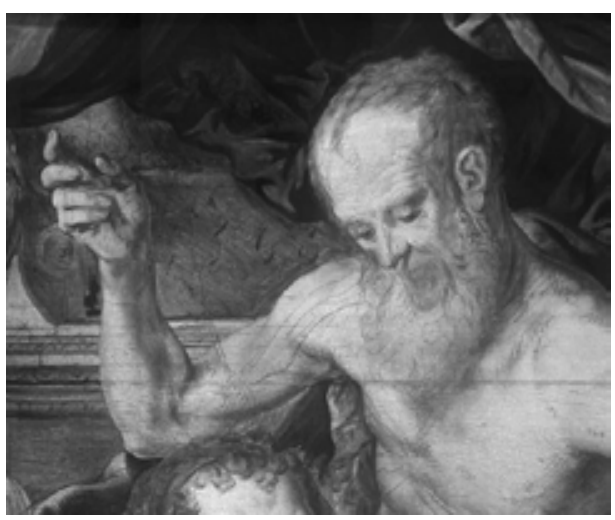

Fig. 27 Joachim Beuckelaer, Isaac Blessing Jacob, Utrecht (fig. 26). IRR digital composite of Isaac's upper body, ( RKD, The Hague

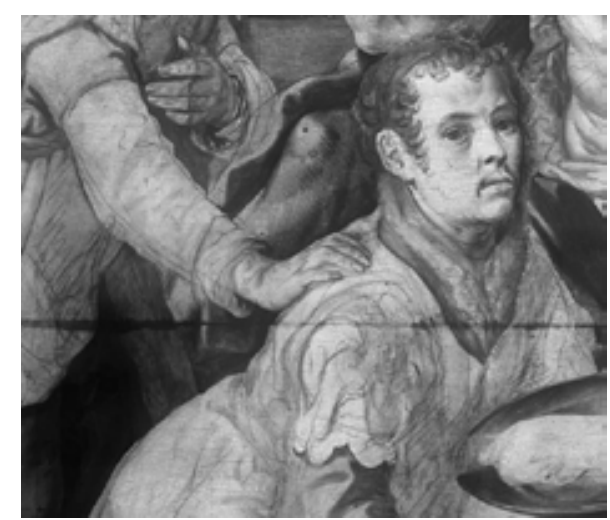

Fig. 28 Joachim Beuckelaer, Isaac Blessing Jacob, Utrecht (fig. 26). IRR digital composite of Isaac's leg, which has been painted out, @ RKD, The Hague

The underdrawing makes it clear that the artist was sketching freely as he prepared the composition on the panel. This can easily be seen in the changes in Isaac (fig. 27). Both arms were different in the underdrawing, and a number of lines were repeated as the artist searched for the final form of the upper arm giving the gesture of blessing. The underdrawn right arm was intended to be much more foreshortened than in the final paint surface. ${ }^{74}$ This was true of the underdrawn left 
arm as well, although to a lesser degree. Thus the arms were originally closer to the drawing (fig. 25), where Isaac's torso is also seen more on an angle. In the painting, the old man's leg appears as a vague form (fig. 28). When viewed with IRR, it is clear that Isaac's knee appears behind Jacob's head, but it is awkwardly placed relative to the rest of his body, perhaps explaining why it was eventually painted out. ${ }^{75}$ As regards the figure of Rebecca, her eyes and chin were underdrawn lower and her head appears to have originally been bent more forward (fig. 29). Once again, it can be seen that the underdrawn figures more closely correspond to the forms in the independent drawing.

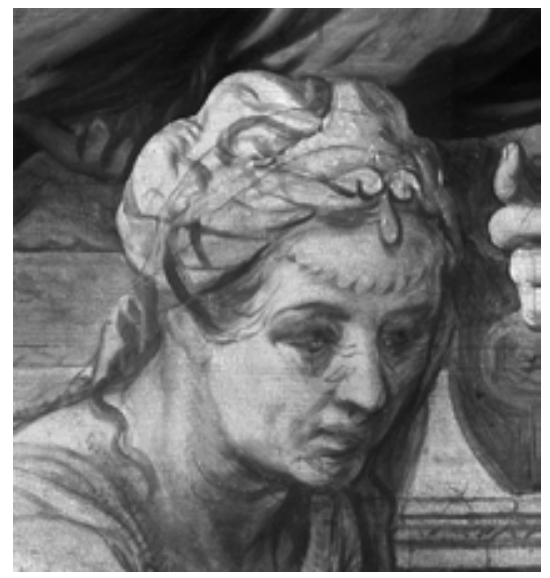

Fig. 29 Joachim Beuckelaer, Isaac Blessing Jacob, Utrecht (fig. 26). IRR digital composite of Rebecca's head, (c) RKD, The Hague

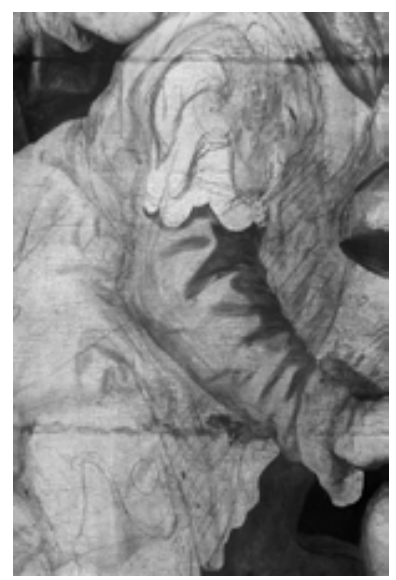

Fig. 30 Joachim Beuckelaer, Isaac Blessing Jacob, Utrecht (fig. 26). IRR digital composite of Jacob's costume, (c) RKD, The Hague

In IRR Jacob's costume has decorative motifs (fig. 30). While these, on the one hand, differentiate the figure from the simpler depiction in the drawing, they also show that the decision to add decoration was made before or during the underdrawing stage. ${ }^{76}$ The right sleeve was initially planned to be cut off short and straight, over a longer one, just as in the Braunschweig drawing and in other examples mentioned above. It was only at a later stage, in chalk, that the lines of decoration were added to the upper arm, indicating once again that changes continued to be made during the underdrawing phase. This motif had still not achieved its definitive form at this point, since if differs from what is now visible in the surface paint. The decoration on the upper leg was not executed at all (fig. 28). What is also obvious is that the fur cuff at the wrist was not indicated as such in the underdrawing. Apparently this was important enough iconographically that it had to be added or enlarged in a later stage. Dark paint, however, makes it difficult to determine whether or not the goat skin on Jacob's neck was already present in the underdrawing. ${ }^{77}$

The underdrawing in the furniture again corresponds to the drawing. The feet of the table holding bread and a wine glass curl inward in the paint surface, while they curve out in the underdrawing, as they do in the drawing (fig. 31). The feet of Rebecca's stool curve outward too (fig. 32), indicating that the stool originally showed more similarities to the model in the drawing as well.

The roast goat, which is important to the narrative, was probably only added during the application of paint. The tin platter holding the meat was painted with a mixture of pigments impenetrable to IRR, and as a result, it is impossible to detect any contours that might have defined 


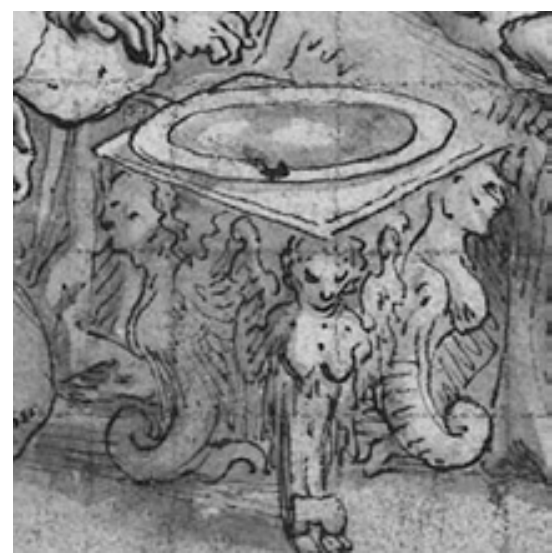

Fig. 31a Joachim Beuckelaer, Isaac Blessing Jacob, Braunschweig (fig. 25). Detail of the table on the right (reversed)

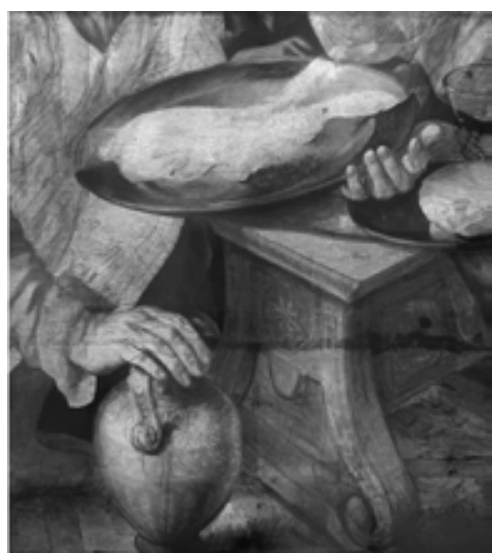

Fig. 31b Joachim Beuckelaer, Isaac Blessing Jacob, Utrecht (fig. 26). IRR digital composite of the table on the right, @ RKD, The Hague

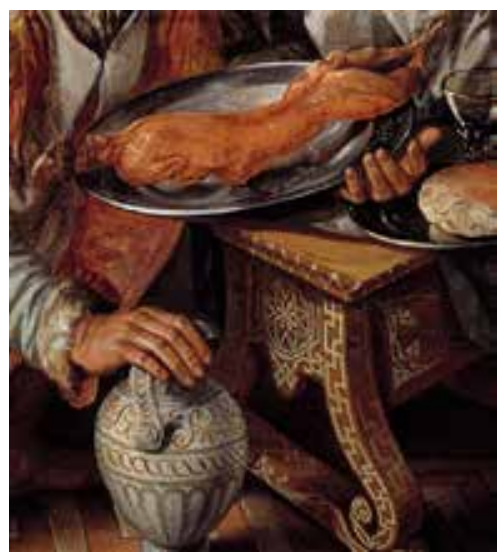

Fig. 31c Joachim Beuckelaer, Isaac Blessing Jacob, Utrecht (fig. 26). Detail of the table on the right

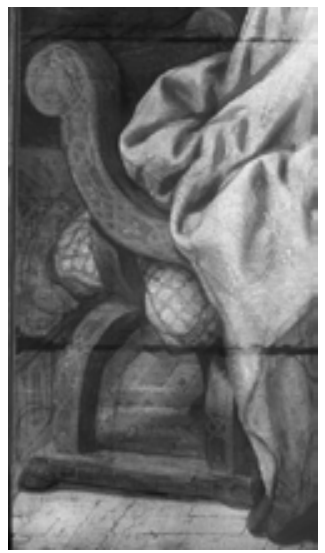

Fig. 32 Joachim Beuckelaer, Isaac Blessing Jacob, Utrecht (fig. 26). IRR digital composite of Rebecca's stool, @ RKD, The Hague

the shape of the goat. There are, nonetheless, no lines to be seen inside the form of the goat, nor is there any preparation in chalk for the goat's legs, which stick out over the edge of the platter. Moreover, the goat's head and legs have been added on top of the already-painted figures of Jacob and Isaac. ${ }^{78}$ This leads to the conclusion that the roasted meat was added only as work on the composition was still progressing. Because the goat was delimited by the paint of the platter, the addition cannot have occurred in the very last stage of the creative process.

41 In this case, as in that of the St. Ursula painting, the very elaborate underdrawing seems to be earlier than the date of 1568 given on the painting. The underdrawing might be closer to the drawing done in 1561. On the other hand, dendrochronology has shown that use of the panel before 1568 is not probable. ${ }^{79}$ This work may have required a more detailed underdrawing, since the subject was an uncommon one for Beuckelaer at this point in his career and had specific iconographic demands. In the second half of the 1560s Beuckelaer focused more and more on market and kitchen pieces. ${ }^{80}$ The deviations the artist made from the drawing on paper may also have required more searching in the underdrawing for satisfactory forms and positioning. Since it is likely that this painting is the result of a commission, the more elaborate underdrawing may have served additionally as a contract design, a so-called vidimus, for the person ordering the work. 


\section{Concluding Remarks}

427 he comparisons above between drawings, underdrawings, and the painted surfaces of several works by Joachim Beuckelaer lead to a number of conclusions. First, it appears that in the artist's design process, no distinction was made on the basis of the medium of the final work. This is exemplified by the drawing for stained glass with the Adoration of the Shepherds in Hamburg, which played a role in the evolution of the painting in Court-Saint-Etienne, and the two oil sketches in the Louvre, which were transformed into a painted Crucifixion, also in the Louvre. ${ }^{81}$ Designs for stained-glass windows were thus assimilated by the studio into the process of creating painted compositions.

43 It has been shown that the painter generally took the same approach to his drawn models. In each case the artist revised the composition as compared with the original design. There is a general similarity in the way the artist compressed the compositions, as evidenced by the works in Cologne, Court-Saint-Etienne, and Utrecht. Reversals of figures and sections of compositions have been noted (Court-Saint-Etienne and Utrecht), as well as exchanges in posture between two figures (Cologne and the Louvre). Also, research has revealed that in a number of cases the underdrawing is closer to the model than the final painted solution. Designing did not stop with the execution of a drawing on paper but was ongoing, continuing into the layout of the underdrawing as well as into the application of the paint layers. Yet this appears to have occurred to a lesser extent in the Court-Saint-Etienne painting.

44 Squaring is another, related issue. Even if a grid pattern can be ascertained in a drawing or in an underdrawing, it does not necessarily follow that there is a direct connection between the squared drawing and the associated painting. Squaring on a drawing does not always indicate that it was actually put into use transferring the composition to the final support. ${ }^{82}$

The many modifications that were revealed by comparing drawing, underdrawing, and painting bring up the question of who dictated these changes. Was it the painter himself, or did a client or commissioner determine the final appearance of a work? Examples are known where the person ordering the work exerted a direct influence on the preparation or the painting activity leading to the final image. Archival documents relate that while work was proceeding on the Coronation of the Virgin by the Bruges painter Albert Cornelis, the commissioners lodged a complaint because the work had not been painted according to agreed-upon requirements. ${ }^{83}$ According to the court documents, the painter was supposed to paint the seven choirs of angels with their proper attributes. Eventually it was decided that Cornelis would be allowed to finish the project, but that he must do that following the established requirements. IRR research of the panel makes it clear that the painter must have heard the commissioners' complaint while he was at work on the painting. In the underdrawing and also in the first paint layer, the angels were depicted with folded or raised hands, but no attributes. In their final forms, the angels take more varied postures, and they are depicted with their correct attributes. ${ }^{84}$ Pieter Pourbus's Triptych with Joos van Belle in the church of St. James, Bruges, provides another example.$^{85} \mathrm{~A}$ modello has been preserved with inscriptions that prove that the drawing served as a vidimus for the triptych. ${ }^{86}$ In the drawing Mary is shown drying her tears. Apparently Van Belle was not satisfied with this motif, and he agreed with Pourbus that the artist would paint Mary with crossed arms, as the inscription along the lower edge states ${ }^{87}$ IRR examination of the panel revealed that the correction in Mary's posture 
had already been made by the underdrawing stage. Although small changes continued into the painting stage, distinct steps can be discerned in the process: the planning of the composition in the drawing, the adjustment as ordered by the client, and its subsequent execution on the panel. This differs markedly from the ongoing creative process that distinguishes Beuckelaer's work. Since the changes that occur in Beuckelaer's works are of like kind, it is probable that the artist himself had considerable input in the actual process of making the revisions. It is also quite likely that drawings functioned in the atelier as part of a collection of models from which clients could make a selection. ${ }^{88}$ The actual models--whether a drawing, underdrawing, or painting--may have played a role in the purchasing process by providing a basis for suggested modifications. It must still have been the artist, however, who was the most decisive factor. ${ }^{89}$ The constant adjustment of forms during the drawing and painting process implies that a fixed idea of the composition could never have been established with the client. It is, of course, also feasible that some of these works were intended for the open market, making it even more evident that modifying and changing compositions was an artistic imperative for Beuckelaer.

\section{Acknowledgments}

I am especially grateful to Molly Faries for the translation of this article. A Dutch version of the text can be found in my PhD dissertation (see note 5), pp. 103-46. For their understanding and support, I am indebted to the churches and museums where IRR examinations were carried out on the paintings under their care. Additional thanks are due to J. R. J. van Asperen de Boer, Peter van den Brink, Adri Verburg, Micha Leeflang, and Claudine Chavannes for their cooperation during the IRR research of the works discussed here.

Margreet Wolters has been employed since 1997 at the RKD (Netherlands Institute for Art History) in The Hague as Scientific Research Associate in IRR and Curator of Technical Documentation. From 1994 to 1999 she participated in a research project on the working methods and workshop practices of Pieter Aertsen, Joachim Beuckelaer, and painters from their circle. Her dissertation on the function of underdrawings in paintings by Joachim Beuckelaer was completed in 2011 for the University of Groningen. She has also participated in various exhibitions and cataloguing projects, often directing the IRR study.

\section{List of Illustrations}

Fig. 1 Joachim Beuckelaer, Adoration of the Shepherds, dated 1560, pen in brown ink, with gray washes, squaring in red chalk, 175 x 157 mm. New York, The Metropolitan Museum of Art (Bequest of Harry G. Sperling 1975), inv. no. 1975.131.137 (artwork in the public domain) Photo: metmuseum.org

Fig. 2 Joachim Beuckelaer, Adoration of the Shepherds, pen in brown ink, squaring in red chalk, 180 x 162 mm. Haarlem, Teylers Museum (collection Matthijs de Clercq), inv. no.KT 2011:031 (artwork in the public domain)

Fig. 3 Joachim Beuckelaer, Adoration of the Shepherds, dated 1565, panel, $141 \mathrm{x} 107 \mathrm{~cm}$. Cologne, church of St. Ursula (artwork in the public domain) photo: Peter van den Brink 
Fig. 4a Joachim Beuckelaer, Adoration of the Shepherds, Haarlem (fig. 2). Detail of the right arm and hand of the shepherd on the left.

Fig. $4 \mathrm{~b}$ Joachim Beuckelaer, Adoration of the Shepherds, Cologne (fig. 3). IRR digital composite of the right arm and hand of the shepherd on the left, (C) RKD, The Hague

Fig. 4c Joachim Beuckelaer, Adoration of the Shepherds, Cologne (fig. 3). Detail of the right arm and hand of the shepherd on the left.

Fig. 5 Joachim Beuckelaer, Adoration of the Shepherds, Cologne (fig. 3). IRR digital composite of the hat of the shepherd on the left, (C) RKD, The Hague

Fig. 6 Joachim Beuckelaer, Adoration of the Shepherds, Cologne (fig. 3). IRR digital composite of the Christ child's arms, (C) RKD, The Hague

Fig. 7 Joachim Beuckelaer, Adoration of the Shepherds, Cologne (fig. 3). IRR digital composite of the Christ child's crib, (C) RKD, The Hague

Fig. 8 Joachim Beuckelaer, Adoration of the Shepherds, Cologne (fig. 3). Infrared photograph of the head of Mary

Fig. 9 Joachim Beuckelaer, Adoration of the Shepherds, Cologne (fig. 3). IRR digital composite of the head of the shepherdess, (c) RKD, The Hague

Fig. 10 Joachim Beuckelaer, Two Market Women, dated 1561, panel, 124.5 x $92.7 \mathrm{~cm}$. Vienna, Kunsthistorisches Museum, inv. no. 3559. IRR digital composite of the head of the woman on the right, (C) RKD, The Hague

Fig. 11 Joachim Beuckelaer, Adoration of the Shepherds, monogrammed and dated 1565, panel, 140 x $110 \mathrm{~cm}$. Court-Saint-Etienne (Belgium), church of St. Etienne (artwork in the public domain) Photo: Peter van den Brink

Fig. 12 Joachim Beuckelaer, Adoration of the Shepherds, dated 1563, pen in brown ink, with brown washes, traces of squaring, 400 x 190 mm. Hamburg, Hamburger Kunsthalle, inv. no. 21626 (artwork in the public domain)

Fig. 13 Joachim Beuckelaer, Adoration of the Shepherds, Court-Saint-Etienne (fig. 11). IRR digital composite of the head of Mary, (C) KIK-IRPA, Brussels

Fig. 14 Joachim Beuckelaer, Vegetable Seller, dated 1564, panel, 114.8 x $170.5 \mathrm{~cm}$. Kassel, Staatliche Museen, Gemäldegalerie Alte Meister, inv. no. GK 41. IRR digital composite of the woman's head, (c) RKD, The Hague

Fig. 15 Joachim Beuckelaer, Adoration of the Shepherds, Court-Saint-Etienne (fig. 11). IRR digital composite of the old shepherdess, (C) KIK-IRPA, Brussels 
Fig. 16 Joachim Beuckelaer, Adoration of the Shepherds, Court-Saint-Etienne (fig. 11). IRR digital composite of the shepherd's sleeve, (c) KIK-IRPA, Brussels

Fig. 17a Joachim Beuckelaer, left half of a Crucifixion with the two thieves, oil paint on reddish-brown prepared paper, 312 x $236 \mathrm{~mm}$ (with angled upper corners). Paris, Musée du Louvre, Département des Art Graphiques, inv. no. 20701 (artwork in the public domain) Photo: () Musée du Louvre / Micha Leeflang

Fig. 17b Joachim Beuckelaer, right half of a Crucifixion with the crucified Christ, monogrammed, oil paint on reddish-brown prepared paper, $308 \times 242 \mathrm{~mm}$ (with angled upper corners). Paris, Musée du Louvre, Département des Art Graphiques, inv. no. 20709 (artwork in the public domain) Photo: (C) Musée du Louvre / Micha Leeflang

Fig. 18 Joachim Beuckelaer, Crucifixion, monogrammed and dated 1567, panel, 56.5 x $56 \mathrm{~cm}$. Paris, Musée du Louvre, inv. no. RF 1997-6 (artwork in the public domain)

Fig. 19a Joachim Beuckelaer, left half of a Crucifixion with the two thieves, Paris (fig. 17a). IRR digital composite, (c) RKD, The Hague

Fig. 19b Joachim Beuckelaer, right half of a Crucifixion with the crucified Christ, Paris (fig. 17b). IRR digital composite, (c) RKD, The Hague

Fig. 20 Joachim Beuckelaer, Crucifixion, Paris (fig. 18). IRR digital composite showing the squaring, (c) RKD, The Hague

Fig. 21a Joachim Beuckelaer, left half of a Crucifixion with the two thieves, Paris (fig. 17a). IRR digital composite of the figure with a basket holding tools, (c) RKD, The Hague

Fig. 21b Joachim Beuckelaer, left half of a Crucifixion with the two thieves, Paris (fig. 17a). Detail of the figure with a basket holding tools

Fig. 21c Joachim Beuckelaer, Crucifixion, Paris (fig. 18). IRR digital composite of the figure with a basket holding tools, (c) RKD, The Hague

Fig. 21d Joachim Beuckelaer, Crucifixion, Paris (fig. 18). Detail of the figure with a basket holding tools

Fig. 22 Joachim Beuckelaer, Crucifixion, Paris (fig. 18). IRR digital composite of the two thieves, (C) RKD, The Hague

Fig. 23 Joachim Beuckelaer, Crucifixion, Paris (fig. 18). IRR digital composite of the figures under the cross on the right, (C) RKD, The Hague

Fig. 24 Joachim Beuckelaer, Crucifixion, Paris (fig. 18). IRR digital composite of the architecture, 
(C) RKD, The Hague

Fig. 25 Joachim Beuckelaer, Isaac Blessing Jacob, dated 1561, pen in gray ink, with gray washes, squaring in red chalk, 168 x 243 mm. Braunschweig, Herzog Anton Ulrich-Museum, inv. no. Z 1147 (artwork in the public domain)

Fig. 26 Joachim Beuckelaer, Isaac Blessing Jacob, monogrammed and dated 1568, panel, $112.3 \mathrm{x}$ $170.8 \mathrm{~cm}$. Utrecht, Museum Catharijneconvent, inv. no. BMH s76 (artwork in the public domain) Photo: (C) Museum Catharijneconvent, Utrecht / Ruben de Heer

Fig. 27 Joachim Beuckelaer, Isaac Blessing Jacob, Utrecht (fig. 26). IRR digital composite of Isaac's upper body, (C) RKD, The Hague

Fig. 28 Joachim Beuckelaer, Isaac Blessing Jacob, Utrecht (fig. 26). IRR digital composite of Isaac's leg, which has been painted out, (C) RKD, The Hague

Fig. 29 Joachim Beuckelaer, Isaac Blessing Jacob, Utrecht (fig. 26). IRR digital composite of Rebecca's head, (c) RKD, The Hague

Fig. 30 Joachim Beuckelaer, Isaac Blessing Jacob, Utrecht (fig. 26). IRR digital composite of Jacob's costume, (c) RKD, The Hague

Fig. 31a Joachim Beuckelaer, Isaac Blessing Jacob, Braunschweig (fig. 25). Detail of the table on the right (reversed).

Fig. 31b Joachim Beuckelaer, Isaac Blessing Jacob, Utrecht (fig. 26). IRR digital composite of the table on the right, (C) RKD, The Hague

Fig. 31c Joachim Beuckelaer, Isaac Blessing Jacob, Utrecht (fig. 26). Detail of the table on the right.

Fig. 32 Joachim Beuckelaer, Isaac Blessing Jacob, Utrecht (fig. 26). IRR digital composite of Rebecca’s stool, (c) RKD, The Hague

${ }^{1}$ See, for instance, Jan van Looveren, “Toelichting bij de restauratie van vier schilderijen van Joachim Beuckelaer," in Joachim Beuckelaer: Het markt- en keukenstuk in de Nederlanden 1550-1650, exh. cat., ed. Paul Verbraeken (Ghent, Museum voor Schone Kunsten, 1986-87), 78-86, esp. 80, and Margreet Wolters, "Creativity and Efficiency: Aspects of Joachim Beuckelaer's Use of Models and Patterns," in Making and Marketing:Studies of the Painting Process in Fifteenth-and Sixteenth-Century Netherlandish Workshops, ed. Molly Faries (Turnhout, 2006), 155-78.

${ }^{2}$ Ainsworth rightly cautioned that a sketchy and loosely drawn underdrawing need not always indicate the first, experimental layout of the composition on the support; see Maryan W. Ainsworth, 
"Old Assumptions Reconsidered through Revised Methodologies," in Le dessin sous-jacent et la technologie dans la peinture, Colloque XI, 14-16 septembre 1995 (Dessin sous-jacent et technologie de la peinture: Perspectives), ed. Roger van Schoute and HélèneVerougstraete (Louvain-la-Neuve, 1997), 103-8, esp. 103.

${ }^{3}$ For Beuckelaer's handling of models, see Joachim Beuckelaer(see note 1 above), various entries; Lorne Campbell, "Beuckelaer's The Four Elements: Four Masterpieces by a Neglected Genius," Apollo (Feb. 2002), 40-46; Margreet Wolters, “Two Vegetable Sellers by Joachim Beuckelaer: A Symbiotic Relationship," in Le dessin sous-jacent et la technologie dans la peinture, Colloque XV, Brugge, 11-13 septembre 2003 (La peinture ancienne et ses procédés: Copies, répliques, pastiches), ed. Hélène Verougstraete and Jacqueline Couvert (Leuven, 2006), 159-67; and Wolters, "Creativity and Efficiency," 2006 (see note 1).

${ }^{4}$ See Wouter Th. Kloek, "De tekeningen van Pieter Aertsen en Joachim Beuckelaer," Nederlands Kunsthistorisch Jaarboek 40 (1989): 129-66.

${ }^{5}$ For the relationship between Pieter Aertsen's Christ in the House of Mary and Martha or his paintings of the Kitchen Maid and Beuckelaer's Kitchen Scene with Christ in the House of Mary and Martha, see Margreet Wolters, "'Met kool en crijt': De functie van de ondertekening in de schilderijen van Joachim Beuckelaer," PhD diss. (Rijksuniversiteit Groningen, 2011), 189-208. ${ }^{6}$ See, for instance, Keith P. F. Moxey, “The 'Humanist' Market Scenes of Joachim Beuckelaer: Moralizing Exempla or 'Slices of Life,"Jaarboek van het Koninklijk Museum voor Schone Kunsten (1976): 109-87, esp. 113-27; and Wolters, "Creativity and Efficiency" (note 1), 164-73. ${ }^{7}$ Kloek assumed the same thing: "de bewaarde tekeningen geven waarschijnlijk slechts een summier beeld van de activiteit van Beuckelaer als tekenaar." Kloek, "De tekeningen"(note 4),134. That many more models must have existed was also noted in Wolters, "Two Vegetable Sellers" (note 3) and Wolters "Creativity and Efficiency" (note 1).

${ }^{8}$ See Maximiliaan P. J. Martens, "De dialoog tussen artistieke traditie en vernieuwing," in Brugge en de Renaissance: Van Memling tot Pourbus, exh. cat., ed. Maximiliaan P. J. Martens (Bruges, Memlingmuseum and Oud-Sint-Janshospitaal, 1998), 58-59, catalogue volume 43-63.

${ }^{9}$ See, for example, Brugge en de Renaissance (note 8), $59 \mathrm{n} 92$.

${ }^{10}$ See, for instance, Molly Faries, "Reshaping the Field: The Contribution of Technical Studies," in Early Netherlandish Painting at the Crossroads: A Critical Look at Current Methodologies, ed. Maryan W. Ainsworth (New Haven, Conn., 2001), 70-105, esp. 84-101; Molly Faries, “Technical Studies of Early Netherlandish Painting: A Critical Overview of Recent Developments," in Recent Developments in Technical Examination of Early Netherlandish Painting: Methodology, Limitations and Perspectives, ed. Molly Faries and Ron Spronk (Turnhout, 2003), 1-37, esp. 22; Molly Faries, "Making and Marketing: Studies of the Painting Process," in Making and Marketing: Studies of the Painting Process in Fifteenth- and Sixteenth-Century Netherlandish Workshops, ed. Molly Faries (Turnhout, 2006), 9-10.

${ }^{11}$ Karel van Mander, Den Grondt der edel vry schilder-const, edited, translated, and annotated by H. Miedema (Utrecht, 1973),Grondt, pt. 1, p. 201. See also Jacqueline M. C. Boreel and Francis W. H. van Zon-Christoffels, "Enkele aspecten van de schilderspraktijk in het atelier van Pieter Aertsen natuurwetenschappelijk nader bekeken," Nederlands Kunsthistorisch Jaarboek 40 (1989): 167-96, esp. 172-74.

${ }^{12}$ Yvette Bruijnen, "Fruit and Vegetables: New Information on the Workshop Practice of Pieter Aertsen," Oud Holland 108 (1994): 120-26. Beuckelaer appears not to have used cartoons for details, see Campbell 2002 (note 3), 44; Wolters, "Creativity and Efficiency"(note 1); Lorne Camp- 
bell and Susan Foister, “The Artists of the North, Their Drawings and Underdrawings",in Art in the Making: Underdrawings in Renaissance Paintings, exh. cat., ed. David Bomford (London, The National Gallery, 2002-3), 38-52, esp. 48. However, a cartoon may have been used for the figures in two depictions of the Vegetable Seller, see Wolters “Two Vegetable Sellers" (note 3).

${ }^{13}$ Since Van Mander specifically singles out Aertsen's use of cartoons, it may have been an unusual working method. Therefore, it is not certain whether or not Beuckelaer actually took over this procedure.

${ }^{14}$ See also Jeltje Dijkstra, “Origineel en kopie: Een onderzoek naar de navolging van de Meester van Flémalle en Rogier van der Weyden," PhD diss. (University of Amsterdam, 1990), 52.

${ }^{15}$ See below for the basic information about the various works.

${ }^{16}$ The oil sketch The Trickery of the Gibeonites, from a series of four sheets, is now in the J. Paul Getty Museum, Los Angeles (inv. no. 90.GG.133). The Execution of the Five Kings of the Amorites, from the same series, is in the Metropolitan Museum of Art, New York (Harry G. Sperling Fund, 2001, inv. no. 2001.109).

${ }^{17}$ See Kloek, "De tekeningen" (note 4), 133-36 and 153-63.

${ }^{18}$ Verbraeken (in Joachim Beuckelaer[note 1], 131, cat. no. 12) argued for an attribution to Joachim Beuckelaer. Kloek ("De tekeningen" [note 4], 164, no. nB.1) rightly noted the rigid manner of drawing indicative of a copy and proposed that the drawing was done after the lost work by Beuckelaer illustrated in Willem van Haecht's Apelles Painting Campaspe in the Mauritshuis in The Hague (inv. no. 266). See also Frits Lugt, "Joachim Beuckelaer als tekenaar,"Kunsthistorische Mededelingen van het Rijksbureau voor Kunsthistorische Documentatie te 's-Gravenhage 3 (1948): 45-47. The work is also depicted in another painting by Van Haecht, for which, see Kamers vol Kunst in zeventiende-eeuws Antwerpen, exh. cat., ed. Ariane van Suchtelen and Ben van Beneden (Antwerp, Rubenshuis, and The Hague, Koninklijk Kabinet van Schilderijen Mauritshuis, 2009-10), 123, 130-31.

${ }^{19}$ This concerns two related sheets, one an unidentified clemency scene and the other perhaps depicting the Departure of the Prodigal Son, although this is not entirely certain, see Kloek, "De tekeningen"(note 4), 158-59, nos. B.6, B.7.

${ }^{20}$ The drawings and models for Beuckelaer's market and kitchen pieces may have been lost through frequent use. See also Dijkstra1990 (note 14), 52. It is also possible that instead of overall compositional studies, only loose motifs were needed as models for these more standardized representations (see also note 7 above). With thanks to Rudi Ekkart for this suggestion.

${ }^{21}$ New York, The Metropolitan Museum of Art (bequest of Harry G. Sperling 1975, inv. no. 1975.131.137); 175 x 157 mm. Kloek “De Tekeningen" (note 4), 153, no. B.1: pen in brown ink over traces of black chalk on brown paper, squared in red chalk, with gray washes added by a later hand.

${ }^{22}$ See also Kloek, "De tekeningen" (note 4), 154.

${ }^{23}$ Two Market Women, panel, 124.5 x $92.7 \mathrm{~cm}$, not signed, dated 1561, Vienna, Kunsthistorisches Museum (inv. no. 3559) and Market Scene with Ecce Homo, panel, 121.5 x $166 \mathrm{~cm}$, not signed, dated 1561, Stockholm, Nationalmuseum (inv. no. NM 321).

${ }^{24}$ Wouter Th. Kloek, "Pieter Aertsen en het probleem van het samenstellen van het oeuvre," Nederlands Kunsthistorisch Jaarboek 40 (1989): 1-28, esp. 14-15.

${ }^{25}$ Panel, $97 \times 141 \mathrm{~cm}$, marked with a trident, dated 1554? (the date is unclear), Amsterdam, Amsterdam Museum (inv. no. SA 6061) and panel, 87 x $63 \mathrm{~cm}$, Rouen, Musée des Beaux-Arts (inv. no. 907.1.84); the date of the latter is ca. 1560 according to Mary Braman Buchan, "The 
Paintings of Pieter Aertsen," PhD diss. (Institute of Fine Arts, New York University, 1975), 213. In its complete state the fragment with the Adoration of the Shepherds in the Amsterdam Museum (panel, 89.9 x $59.2 \mathrm{~cm}$, neither signed nor dated [inv. no. SA 7255]), may also have played a role. See also Ruth Ehmke, "Ein Tafelbild der Geburt Christi in der Ursulakirche zu Köln," Jahrbuch der rheinischen Denkmalpflege 27 (1967): 223-51, esp. 247, where it is noted that the Cologne work derives from one of Aertsen's inventions.

${ }^{26}$ Pen on paper, $180 \times 162 \mathrm{~mm}$, squared with red chalk, upper corners cut off, Haarlem, Teylers Museum (collection Matthijs de Clercq) (inv. no. TK 2011:031).

${ }^{27}$ Panel $141 \times 107 \mathrm{~cm}$, not signed, dated 1565, Cologne, church of St. Ursula.

${ }^{28}$ For the 1560 drawing, see Kloek, "De tekeningen" (note 4), 153-54, no. B.1. Kloek feels that the drawing may show corrections by Beuckelaer's master, Aertsen, and that the washes are of a later date.

${ }^{29}$ For changes in the sheet dated 1560, see Kloek, "De tekeningen" (note 4), 154.

${ }^{30}$ The antique fragments have been taken from the frontis piece in Sebastiano Serlio, Het derde Boeck, Handelende van de aldervermaerste Antique edificien van Templen / Theatren / Amphitheatren / Paleysen / Thermen / Obelischen / Brugghen / Archen-triumphal / etc. Beschreven eñ gefigureert met haren gronden ende maten: ooc de plaetsen daer sestaen/ende wiese dede maken, 1553. ${ }^{31}$ It cannot be excluded that there was a drawing that served as an intervening step. A panel with the Adoration of the Sheperds (private collection) has just recently appeared and would have been interesting to include in these comparisons, but IRR analysis was not possible prior to publication of this article.

${ }^{32}$ Sebastiano Serlio, Het derde Boeck(note 30), fol. 32 recto. See also Ehmke 1967 (note 25), 249. ${ }^{33}$ Kloek identifies the older woman behind the crib as the midwife who attended Christ's birth, see Kloek, "De tekeningen"(note 4), 159. Since this can only be tentative, she is here called a shepherdess.

${ }^{34}$ The position of the ox's head, although reversed, is similar to that in Pieter Aertsen's Adoration of the Shepherds at Rouen. Only the head and forefoot of the ox are visible at Rouen (for the painting's basic information, see note 25 above). See also Ehmke1967 (note 25), 250.

${ }^{35}$ See also note 30.

${ }^{36}$ The panel was investigated on January 31, 1997, by the author and Peter van den Brink, in the company of Godehard Hoffmann of the Rheinische Denkmalpflege. The IRR examination was done with a Hamamatsu C2400 camera outfitted with a N 2606-06 select IR vidicon, a Nikon Micro-Nikkor 1:2.8/55 mm lens, a Kodak Wratten 87C filter, with a Lucius \&Baer VM 1710 monitor (625 lines). Digital capture was done with a Meteor RCB frame grabber, 768 x 574 pixels, a color vision tool kit (Visual basic). The IRR composites were made with Adobe Photoshop. The paintings discussed here were investigated in the context of a research project studying the working procedure and studio practice of Pieter Aertsen and Joachim Beuckelaer, along with several masters in their circle such as Jan van Hemessen, Jan van Amstel, and Pieter Pietersz. The Rijksuniversiteit Groningen and the RKD collaborated in this project, which was funded by NWO/VNC (Vlaams-Nederlands Comité voor Nederlandse taal en cultuur). Others participating in the project were Reindert Falkenburg, J. R. J. van Asperen de Boer, Max Martens, and Peter van den Brink.

${ }^{37}$ It cannot be excluded that there was an earlier, painted version in which the changes had already been introduced.

${ }^{38}$ For the 1560 drawing in the Metropolitan Museum of Art, see Kloek, "De tekeningen" (note 4), 
153. The squaring could also have been added to the drawing (much) later.

${ }^{39}$ That a squared drawing does not always lead to squaring in a painting has also been noted with Aertsen. Although a squared drawing exists for the left exterior wing depicting Saint Martin and the Beggar in theSeven Sorrows of Mary altarpiece in Zoutleeuw, IRR detected no traces of a grid in the painting. Because the drawing and painting are almost identical in this instance, it was assumed that the composition was transferred by means of the squaring to a cartoon for the wing, see Boreel and Van Zon-Christoffels "Enkele aspecten" (note 11), 174. This possibility does not seem relevant for Beuckelaer, given the looseness of the underdrawing and the differences between the drawing and underdrawing, as discussed.

${ }^{40}$ In her article on the restoration of the work, Ehmke concluded on the basis of infrared photographs, that "im wichtigsten zeichnerischen Detail die farbige Ausformung meist getreu der Zeichnung folgt, darüber hinaus, daß Zeichnung und Malerei durch eine vom ersten Strich an wirksame intensive Bildvorstellung des Malers zu einer fugenlosen Einheit verschmolzen sind. Ehmke 1967 (note 25), 225. As an example she refers to Mary's face, where the underdrawing is indeed quite closely followed. She, however, ignores the many changes revealed by IRR, which are also partially visible in the infrared photographs she publishes.

${ }^{41}$ The position of the hand with shepherd's crook also shows some similarity to the shepherd's right arm on the left side of the design for the large window of the same subject (fig. 12), pen in brown ink with brown washes, traces of squaring, $400 \times 190 \mathrm{~mm}$, not signed, dated 1563. Hamburg, Hamburger Kunsthalle (inv. no. 21626). Kloek, "De tekeningen” (note 4), 159-60, no. B.8. ${ }^{42}$ Although the underdrawing material in the paintings discussed here has not been analyzed, visually, it appears to be a dry material that can be interpreted as black chalk. For the difficulties in identifying underdrawing materials, see Jo Kirby, Ashok Roy, and Marika Spring, "The Materials of Underdrawing," in Art in the Making: Underdrawings in Renaissance Painting, exh. cat., ed. David Bomford (London, The National Gallery, 2002-3), 26-37, esp. 26-27. Analysis of the material used in the underdrawing of Beuckelaer's The Four Elements in the National Gallery, London, proves the material is indeed black chalk, see ibid., 34. See in addition A. Siejek, "Identifikation und Rekonstruktion graphischer Mittel auf dem Malgrund," in Andreas Siejek and Kathrin Kirsch Die Unterzeichnung auf dem Malgrund: Graphische Mittel und Übertragungsverfahren im 15-17. Jahrhundert (Munich, 2004), 13-143.

${ }^{43}$ In the shepherdess's cap a curly line appears that can be compared with that in Rebecca's headdress in a drawing by Beuckelaer from 1561 depicting Isaac Blessing Jacob (fig. 25). Pen in gray ink with gray washes, squared in red chalk, 169 x $244 \mathrm{~mm}$, dated 1561, Braunschweig, Herzog Anton Ulrich-Museum (inv. no. Z 1147). Kloek, "De tekeningen" (note 4), 154-55, no. B.2. This drawing and its relationship to Beuckelaer's painting will be discussed later in this article.

${ }^{44}$ See note 23 for the basic information regarding these paintings.

${ }^{45}$ The remarkably unfinished look of the hair and beard of the standing shepherd and the somewhat sloppy execution of the background figures suggests that the work was not finished with great care. See also Ehmke 1967 (note 25), 125-28.

${ }^{46}$ One, attributed to Pieter Aertsen, is found in a church in Selent in north Germany; panel, 133 x $103 \mathrm{~cm}$, dated 1566, see E. Schlee, "Eine unbekannte Anbetung der Hirten von Pieter Aertsen," Nordelbingen 12 (1936): 124-28. Thanks are owed Truus van Bueren, who kindly placed her documentation of this painting at my disposal. Other versions regularly appear on the art market, just to name a few: canvas, 137 x $103 \mathrm{~cm}$, auction Brussels (Galeries Nackers), June 16-19, 1975, no. 834, as Joachim Beuckelaer; canvas, 132 x 98 cm, auction Brussels (Palais des Beaux-Arts), 
May 14-16, 1968, no. 160. A variant reduced in height, but with the addition of stone steps and a basket of eggs on the left and a landscape in the background: panel, 73 x $94 \mathrm{~cm}$, auction Amsterdam (Christie’s), March 8, 1984, no. 63, as circle of Pieter Aertsen. See also Kloek, "De tekeningen" (note 4), 154.

${ }^{47}$ Panel, 92 x $74 \mathrm{~cm}$, not signed, dated 1561, auction, Wetzlar collection, Amsterdam (Sotheby Mak van Waay), June 9, 1977, no. 43, as Pieter Aertsen. The inscription on this panel, ART.LIGO, remains a puzzle, see also Kloek, "De tekeningen" (note 4), 154. Kreidl sees this as the quasi-signature of an unidentified master who worked in Pieter Aertsen's shop; see Detlev Kreidl, "Die religiöse Malerei Pieter Aertsens als Grundlage seiner künstlerischen Entwicklung,"Jahrbuch der kunsthistorischen Sammlungen in Wien 68 (1972): 43-108, esp. 75; but perhaps the inscription ART.LIGO only means that the composition is a borrowing. See also another painting, panel, 139.7 x $108.5 \mathrm{~cm}$, not signed, dated 1562, auction New York (Christie's), January 19, 1999, no. 72, as Pieter Aertsen.

${ }^{48}$ This occurs more often in copies after Beuckelaer, such as that in the Hamburg Kunsthalle after the Carrying of the Cross in Älvkarleby, which is dated 1563 following the original, but which cannot have originated before 1589, according to dendrochronology. See Margreet Wolters, "Twee Kruisdragingen toegeschreven aan Joachim Beuckelaer: Infraroodreflectografisch onderzoek van de schilderijen te Älvkarleby en Hamburg," inOnverwacht bijeengebracht: Opstellen voor Ed Taverne en Lyckle de Vries ter gelegenheid van hun 25-jarig jubileum in dienst van de Rijksuniversiteit Groningen, ed. Jan L. de Jong and Elwin A. Koster (Groningen, 1996), 149-57, esp. 154. The same phenomenon can be noted in a monogrammed and signed Fish Market in the Bonnefantenmuseum in Maastricht (inv. no. 4029), panel, 117 x $166 \mathrm{~cm}$, which has been provided with the date 1568. Dendrochronology has shown that the panel could not have been painted before 1588 and is more likely to have been done after 1594, making it certain that it is not by Beuckelaer's hand. Report dated September 7, 1998, Peter Klein, Ordinariat für Holzbiologie, Universität Hamburg. ${ }^{49}$ Panel, $140 \times 110 \mathrm{~cm}$, monogrammed and dated 1565, Court-Saint-Etienne (Belgium), church of St. Etienne. For information about the painting, see E. de Corte, "LAAdoration des Bergers Joachim Beuckelaer (1565)," Le Folklore Brabançon: Histoire et vie populaire 241-42 (1980): 457-61 (with an appendix by D. Fallon about the restoration of the panel).

${ }^{50}$ See also note 41 above.

${ }^{51}$ This bending pose also occurs in the figure on the left side of the two early drawings (figs. 1, 2). ${ }^{52}$ The painting was examined on December 3, 1996, by Peter van den Brink and the author. In 2008 Christina Currie documented the panel in its entirety when it was in the atelier of the KIK/ IRPA (Royal Institute of Cultural Heritage, Brussels), with the institute's Inframetrics camera. I am indebted to Christina Currie and Hélène Dubois for discussing the painting and the IRR material with me on May 7, 2008, in the KIK/IRPA in Brussels.

${ }^{53}$ Panel, 114.8 x $170.5 \mathrm{~cm}$, not signed, dated 1564, Kassel, Staatliche Museen, Gemäldegalerie Alte Meister (inv. no. GK 41).

${ }^{54}$ For the observations about changes in the paint layer, X-radiographs were used that belong to KIK/IRPA in Brussels, thanks to Hélène Dubois and Christina Currie.

${ }^{55}$ There is another painting dated just one year later in which the figural group repeats almost exactly, although some adjustments have been made in the background. Panel, $135 \mathrm{x} 108 \mathrm{~cm}$, monogrammed, dated 1566, owned by the Leger Galleries in 1976 (Burlington Magazine [April 1976], lxv and Apollo [May 1976], 125). The tall column bases on the left in the background have now been painted, and the view through the receding arches runs again in this case from the right 
to the left, as at Cologne, while a roof is visible on the right that shows similarities with that on the left side of the drawing in Hamburg.

${ }^{56}$ Kloek, "De tekeningen" (note 4), 162-63, nos. B.10a and B.10b, oil paint on reddish-brown prepared paper, respectively 312 × $236 \mathrm{~mm}$ and 308 × $242 \mathrm{~mm}$ (with angled upper corners), Paris, Musée du Louvre, Département des Art Graphiques (inv. nos. 20701 and 20709).

${ }^{57}$ Panel, 56.5 x $56 \mathrm{~cm}$, monogrammed and dated 1567, Paris, Musée du Louvre (inv. no. RF 19976). Kloek notes a connection between this panel and a small painting by Pieter Aertsen, panel, 28 x $36 \mathrm{~cm}$, Alupka, Alupka Museum; see Wouter Kloek,Pieter Aertsen en de wereld op zijn kop (Amsterdam, 2010), 49, fig. 43.

${ }^{58}$ Kloek, “De tekeningen” (note 4), 163.

${ }^{59}$ The IRR of the painting for this article was documented on June 30, 1998, by the author and Adri Verburg. The equipment used was a Hamamatsu C2400-07 camera outfitted with a N2606 IR vidicon, a Nikon Micro-Nikkor 1:2.8/55 mm lens, a Heliopan RG 850 (or RG 1000) filter, and a Lucius \&Baer VM 1710 monitor (625 lines). Digital capture was done with a Meteor RCB frame grabber, $768 \times 574$ pixels, color vision tool kit (Visualbasic). The sketches were documented on August 26, 2011, by the author and Micha Leeflang using equipment with the same specifications. The IRR composites were made with PanaVue ImageAssembler and Adobe Photoshop. ${ }^{60}$ The squaring measures circa $3.8 / 3.9 \mathrm{~cm}$ between the horizontal and vertical lines. Points for alignment are visible in several places. Kloek ("De tekeningen" [note 4], 159) has also observed this in several of Beuckelaer's drawings. The squaring is laid out from a line along the central axis, with seven lines to the left and right, the outermost two lying just a bit from the side edges of the panel. On the right the verticals do not continue completely through the sky to the upper edge. Horizontal lines at the top and bottom appear not to have been drawn, perhaps because of the eventual transfer of the composition. Not all of the lines can be easily seen; they were perhaps partially brushed away during painting. Some lines were drawn twice; this occurs elsewhere with Beuckelaer, see Kloek, "De tekeningen" (note 4), 155. For squaring in Beuckelaer, see also Wolters 2011 (note 5), 227-48.

${ }^{61}$ As discussed above, a comparable intervening step appears to have existed for the Adoration of the Shepherds. Designing in multiple stages is also known for other artists, see for example, Ainsworth 1997 (note 2), 104-5; Ellen Konowitz, "Drawings as Intermediary Stages: Some Working Methods of Dirck Vellert and Albrecht Dürer Re-examined," Simiolus 20 (1990-91): 143-52 http://dx.doi.org/10.2307/3780739; Ellen Konowitz inThe Luminous Image: Painted Glass Roundels in the Lowlands, 1480-1560, exh. cat., Timothy B. Husband, et al. (New York, The Metropolitan Museum of Art, 1995), 151-53, cat. nos. 74 and 75; Peter van den Brink, "The Artist at Work: The Crucial Role of Drawings in Early Sixteenth-century Antwerp Workshops," Jaarboek Koninklijk Museum voor Schone Kunsten Antwerpen (2004-5): 159-231, esp. 171-72.

${ }^{62}$ Two other versions of this painting exist: auction A. Finoelst collection, Brussels (Georges Giroux), September 26/27, 1927, no. 27, panel, 52 x $58 \mathrm{~cm}$, as “Ecole anversoise (vers 1550)." On a strip on the right there is a date that Kloek interpreted as 1565 ("De tekeningen" [note 4], 163), but--strangely enough--can better be read as 1505. Another, not signed or dated version was auctioned in Paris, June 18, 1992, at CMP, lot no. 3, panel, 55 x $55 \mathrm{~cm}$. Both, however, repeat the image of the painted surface of the Louvre panel and not the underdrawing. More versions could have been worked on simultaneously, based on the Louvre underdrawing, with the same result. Wolters has shown that Beuckelaer did indeed work on two comparable versions at the same time; see Wolters, “Two Vegetable Sellers" (note 3). The example auctioned at Giroux appears to 
have been executed by a follower, see also Kloek, "Pieter Aertsen" (note 24), 27 n37 (as variant by a follower), and Kloek, "De tekeningen" (note 4), 163 (as probably not autograph). It is also possible that the squaring served to transfer and enlarge the composition on a much larger panel; if so, this work is no longer known. With thanks to Peter van den Brink for this suggestion. ${ }^{63} \mathrm{~A}$ rough form can be seen further to the left of the left thief. This is difficult to interpret, but it perhaps represents a first, sketchy placement of this figure, along with his right arm and head bending down.

${ }^{64}$ See also Kloek, "De tekeningen” (note 4), 163.

${ }^{65}$ Because the design was for two windows, it was impossible to position Christ in the center between the two thieves. In the painting at Alupka (see note 57 above), the three crucified figures are again in an asymmetrical arrangement, but since they are seen from another angle, the thieves appear to Christ's left and right. For other examples, see, among others, Lucas Cranach the Elder, Crucifixion, Munich, Bayerische Staatsgemäldesammlung, Alte Pinakothek (inv. no. 1416). In a work by the Virgo Master depicting the Entombment of Christ, there is an asymmetrical crucifixion in the background, where Christ's empty cross appears on one hill and the crosses of the thieves are placed on another hill just slightly off to the side, and below (Saint Louis, The Saint Louis Art Museum (inv. no. 4:1935).

${ }^{66}$ For the specific information, see note 43 above.

${ }^{67}$ Panel, $112.3 \times 170.8 \mathrm{~cm}$, monogrammed and dated 1568, Utrecht, Museum Catharijneconvent (inv. no. BMH s76). Yvette Bruijnen previously noted the relationship between this painting and works by Jan Sanders van Hemessen of the same subject, respectively, panel, $118 \times 150 \mathrm{~cm}$, ca. 1544-45, Munich, Alte Pinakothek (inv. no. 10) and panel, $150 \times 189 \mathrm{~cm}$, signed and dated 1551, Dannemora-Verken, Österbykerk. See Yvette Bruijnen, "Joachim Beuckelaer, Isaak zegent Jakob, 1568, Catharijne Convent, Utrecht," unpublished minor's thesis (University of Groningen, 1988-89), 8. See also Burr Wallen, "Jan van Hemessen, An Antwerp Painter between Reform and Counter-Reform," PhD diss. (University of Michigan, 1976), 305-6, 310-11, nos. 31, 38. Wallen mentions in connection with Hemessen's work in Munich a print with the same subject by AgostinoVeneziano, which in turn was inspired by one of Raphael's fresco's in the Vatican (see ibid., 103-4, figs. 112, 113). Interestingly, the pose of Isaac in the print shows strong similarities with Beuckelaer's figure in the Utrecht painting. Joachim's brother, Huybrecht, is also known to have used prints after Raphael, see Wolters 2011 (note 5), 296-97.

${ }^{68}$ Kloek, "De tekeningen” (note 4), 155.

${ }^{69}$ This pose is almost identical to Joseph's in the drawing in Hamburg (see fig. 12).

${ }^{70}$ The Corinthian fireplace derives from Sebastiano Serlio, Boek IV,Reglen van Metselrijen/op de vijve manieren van Edificien/te wetene/Thuscana/Dorica/Ionica/Corinthia/eñ Composita: Ende daer by gesedt die exemplen vanden Antijquen/die in dmeeste deel met de leeringe van Vitruvio ouercommen. Met noch toeghesedtte figuren die int eerst niet en waren/ende sommige texten vanden Aucteur gebetert hier oock bij gesedt, translated by Pieter Coecke van Aelst (1549), fol. lviii recto. The fireplace itself and the way it has been placed in space show strong similarities to Pieter Aertsen's Vanitas Still Lifewith Christ in the House of Mary and Martha, panel, 60 x $101.5 \mathrm{~cm}$, marked with a trident, dated "1552.25.Julj", Vienna, Kunsthistorisches Museum (inv. no. 6927). For the Doric version, see Serlio, Boek $I V$, fol. xxxiii recto. The wall in the background vignette on the left is perhaps inspired by fol. 1 recto. A triumphal arch shows similar subdivisions on fol. lvi recto, see also Bruijnen 1988-89 (note 67), 8.

${ }^{71}$ See also, Wolters 2011 (note 5), 189-208. 
${ }^{72}$ The painting was documented on April 18, 1988, by J. R. J. van Asperen de Boer, Yvette Bruijen, and Peter van den Brink. The IRR was done with a Grundig FA70 television camera outfitted with a Hamamatsu N 214 IR vidicon (1975), a Kodak 87A filter, a Zoomar 1:2 8/4 cm Macro Zoomatar lens, with a Grundig BG12 monitor (875 lines) and a Nikon camera using Ilford FP 4, ASA 125 film. IRR assemblies were made by Yvette Bruijnen. The painting was documented in its entirety, with the exception of a zone at the bottom, by the author and Micha Leeflang on June 16 and July 14, 2008. For specifications of the equipment, see note 59.

${ }^{73}$ The first description of the IRR reflectograms is given in Bruijnen 1988-89 (note 67), 15-19.

${ }^{74}$ In this respect the drawing and underdrawing appear to relate more to Jan van Hemessen's depiction of this subject in Munich, where Isaac is also sharply foreshortened. It is not impossible that Beuckelaer knew this work. Buchan noted in particular that the "expansive pose" of Isaac in the Hemessen must have been the prototype for the Christ figure in Pieter Aertsen's Christ with Martha and Mary in Brussels (Buchan 1975 [note 25], 136). See also note 67 above.

${ }^{75}$ This has started to show through as the paint has become more transparent over time. For discussion of this phenomenon, see Margreet Wolters and Arie Wallert, "Joachim Beuckelaer, The Well-Stocked Kitchen," in Still Lifes: Techniques and Style; An Examination of Paintings from the Rijksmuseum, exh. cat., ed. Arie Wallert (Amsterdam, Rijksmuseum, 1999), 40-43, esp. 43, cat. no. 1.

${ }^{76}$ This differs from Rebecca's costume, where the decoration was not underdrawn.

${ }^{77}$ In the drawing, a piece of hide is shown as a cuff around the right wrist, but not around the neck. Strips of goat skin appear both in the hands and around the neck in a painting by Hemessen in Munich and in a print by Veneziano; these also appear in the work in Dannemore-Verken (see note 67).

${ }^{78}$ This is difficult to ascertain, because the paint layers of the goat's head have become quite transparent. See also note 75.

${ }^{79}$ As reported by Peter Klein, Ordinariat für Holzbiologie, Universität Hamburg, January 15, 2002: "With a minimum of 2 years for seasoning an earliest creation of the painting is possible from 1562 upwards. Under the assumption of a median of 15 sapwood rings and 2 years for seasoning a creation is plausible from 1568 upwards." This corresponds to the results obtained for other works by Beuckelaer, where the date on the painting is close to the dendrochronology estimate (as for instance the four paintings at Stockholm, see Wolters 2011 (note 5), $19 \mathrm{n} 1$.

${ }^{80}$ See also Wolters 2011 (note 5), 46.

${ }^{81}$ During the creation of paintings significant portions of compositions as well as single motifs were borrowed from designs for stained glass. An example is provided by the sheet with the unidentified clemency scene dated 1562 and the Judgment of Solomon, panel, 98 x 187, monogrammed and dated 1562, Madrid, Patrimonio Nacional, Palacio de San Ildefonso (inv. no. 10014572). The mother on the right side of the painting seems to be a combination of the two foreground figures in the design for the window. The outstretched arms with palms opened upwards and the face of the man in profile are combined with the figure of a woman on the left of the drawing.

${ }^{82}$ Aertsen's wing at Zoutleeuw was mentioned previously, where the drawing on paper was squared but the painted wing not (see note 39). Perhaps the Adoration of the Shepherds that was discovered recently (see note 31 ) will provide new insights into this aspect of working methods. ${ }^{83}$ Bruges, church of St. James, $1517-22$, panel, $175.8 \times 188.8 \mathrm{~cm}$. The wings have not been preserved. 
${ }^{84}$ See Dorien Tamis in Brugge en de Renaissance (note 8), notes volume, 85-86, no. 52; and Dorien Tamis, “The Genesis of Albert Cornelis' 'Coronation of the Virgin' in Bruges,"Burlington Magazine(November 2000): 672-80.

${ }^{85}$ Middle panel, Seven Sorrows of the Virgin, left and right inner wings:Joos van Belle with His Son and Saint Jodocus and Katharina Hylaert and Saint. Catharine; left and right outer wings: Saint Jodocus andSaint Catharine, both in grisaille; signed and dated 1556, panel, $140.5 \mathrm{x} 124 \mathrm{~cm}$ (middle panel), 141.5 x $52.5 \mathrm{~cm}$ (wings). See Brugge en de Renaissance (note 8), notes volume, 128-31, no. 99.

${ }^{86}$ Pen (with black wash in the frame), 203 x 355 mm, Paris, Ecole Nationale Supérieure des Beaux-Arts (inv. no. M 552). See Brugge en de Renaissance (note 8), notes volume, 128, no. 101. ${ }^{87}$ See Brugge en de Renaissance (note 8), notes volume, 128-31, nos. 99-101; for the inscription on the drawing, see p. 128.

${ }^{88}$ Lorne Campbell, "The Early Netherlandish Painters and Their Workshops," in Le dessin sous-jacent dans la peinture: Colloque III, 6-8 septembre 1979 (Le problème Maître de Flémalle - van der Weyden), ed. Dominique Hollanders-Favart and Roger van Schoute (Louvain-la-Neuve 1981), 43-61, esp. 44, 53, 74n15. See also Dijkstra 1990 (note 14), 51; and Van den Brink 2004-5 (note 61).

${ }^{89}$ Comparable working procedures have also been observed in Beuckelaer's market and kitchen pieces, where the reuse of models shows a similar approach, see Wolters, "Creativity and Efficiency" (note 1).

\section{Bibliography}

Ainsworth, Maryan W. “Old Assumptions Reconsidered through Revised Methodologies.” In Le dessin sous-jacent et la technologie dans la peinture, Colloque XI, 14-16 Septembre 1995 (Dessin sous-jacent et technologie de la peinture: Perspectives), edited by Roger van Schoute and Hélène Verougstraete,103-8. Louvain-la-Neuve, 1997.

Boreel, Jacqueline M. C., and Francis W. H. van Zon-Christoffels. "Enkele aspecten van de schilderspraktijk in het atelier van Pieter Aertsen natuurwetenschappelijk nader bekeken." Nederlands Kunsthistorisch Jaarboek 40 (1989): 167-96.

Brink, Peter van den, 'The Artist at Work: The Crucial Role of Drawings in Early Sixteenth-century Antwerp Workshops." Jaarboek Koninklijk Museum voor Schone Kunsten Antwerpen (2004-5): $159-231$.

Brugge en de Renaissance: Van Memling tot Pourbus. 2 vols. Exh. cat. Edited by Maximiliaan P. J. Martens. Bruges, Memlingmuseum and Oud-Sint-Janshospitaal, 1998.

Bruijnen, Yvette. “Joachim Beuckelaer, Isaak zegent Jakob, 1568, Catharijne Convent, Utrecht." Minor's thesis, Rijksuniversiteit Groningen, 1988-89.

Bruijnen, Yvette. "Fruit and Vegetables: New Information on the Workshop Practice of Pieter Aertsen." Oud Holland 108 (1994): 120-26. 
Buchan, Mary Braman. “The Paintings of Pieter Aertsen.” PhD diss., Institute of Fine Arts, New York University, 1975.

Campbell, Lorne. "The Early Netherlandish Painters and Their Workshops."In Le dessin sous-jacent dans la peinture, Colloque III, 6-8 septembre 1979 (Le problème Maître de Flémalle - van der Weyden), edited by Dominique Hollanders-Favart and Roger van Schoute, 43-61. Louvain-laNeuve, 1981.

Campbell, Lorne. "Beuckelaer's The Four Elements: Four Masterpieces by a Neglected Genius." Apollo (Feb. 2002): 40-46.

Campbell, Lorne, and Susan Foister. "The Artists of the North, Their Drawings and Underdrawings." In Art in the Making: Underdrawings in Renaissance Paintings, exh. cat., edited by David Bomford, 38-52. London, The National Gallery, 2002-3.

Corte, E. de. "L'Adoration des Bergers Joachim Beuckelaer (1565)." Le Folklore Brabançon: Histoire et vie populaire 241-42 (1980): 457-61 (with an appendix by D. Fallon about the restoration of the panel).

Dijkstra, Jeltje. "Origineel en kopie: Een onderzoek naar de navolging van de Meester van Flémalle en Rogier van der Weyden.” PhD diss., University of Amsterdam, 1990.

Ehmke, Ruth. "Ein Tafelbild der Geburt Christi in der Ursulakirche zu Köln.” Jahrbuch der rheinischen Denkmalpflege 27 (1967): 223-51.

Faries, Molly. "Reshaping the Field: The Contribution of Technical Studies." In Early Netherlandish Painting at the Crossroads: A Critical Look at Current Methodologies, edited by Maryan W. Ainsworth, 70-105. New Haven, Conn., 2001.

Faries, Molly. "Technical Studies of Early Netherlandish Painting: A Critical Overview of Recent Developments." In Recent Developments in Technical Examination of Early Netherlandish Painting: Methodology, Limitations and Perspectives, edited by Molly Faries and Ron Spronk, 1-37. Turnhout, 2003.

Faries, Molly. "Making and Marketing: Studies of the Painting Process." In Making and Marketing: Studies of the Painting Process in Fifteenth-and Sixteenth-Century Netherlandish Workshops, edited by Molly Faries, 1-14. Turnhout, 2006.

Kamers vol Kunst in zeventiende-eeuws Antwerpen. Exh. cat. Edited by Ariane van Suchtelen and Ben van Beneden. Antwerp, Rubenshuis, and The Hague, Koninklijk Kabinet van Schilderijen Mauritshuis, 2009-10.

Kirby, Jo, Ashok Roy, and Marika Spring. “The Materials of Underdrawing.” In Art in the Making: Underdrawings in Renaissance Painting, exh. cat., edited by David Bomford, 26-37. London, The National Gallery, 2002-3. 
Kloek, Wouter Th. "Pieter Aertsen en het probleem van het samenstellen van het oeuvre." Nederlands Kunsthistorisch Jaarboek 40 (1989): 1-28.

Kloek, Wouter Th. "De tekeningen van Pieter Aertsen en Joachim Beuckelaer." Nederlands Kunsthistorisch Jaarboek 40 (1989): 129-66.

Kloek, Wouter. Pieter Aertsen en de wereld op zijn kop. Amsterdam, 2010.

Konowitz, Ellen. "Drawings as Intermediary Stages: Some Working Methods of Dirck Vellert and Albrecht Dürer Re-examined.” Simiolus 20 (1990-91): 143-52. http://dx.doi.org/10.2307/3780739

Kreidl, Detlev. "Die religiöse Malerei Pieter Aertsens als Grundlage seiner künstlerischen Entwicklung." Jahrbuch der kunsthistorischen Sammlungen in Wien 68 (1972): 43-108.

Looveren, Jan van. "Toelichting bij de restauratie van vier schilderijen van Joachim Beuckelaer." In Joachim Beuckelaer (see above), 78-86.

Lugt, Frits. "Joachim Beuckelaer als tekenaar." Kunsthistorische Mededelingen van het Rijksbureau voor Kunsthistorische Documentatie te 's-Gravenhage 3 (1948): 45-47.

Mander, Karel van. Den Grondt der edel vry schilder-const. 2 vols. Edited, translated, and annotated by H. Miedema. Utrecht, 1973.

Martens, Maximiliaan P. J. "De dialoog tussen artistieke traditie en vernieuwing." In Brugge en de Renaissance (see above), catalogue volume, 43-63.

Moxey, Keith P. F. “The 'Humanist' Market Scenes of Joachim Beuckelaer: Moralizing Exempla or "Slices of Life." Jaarboek van het Koninklijk Museum voor Schone Kunsten (1976): 109-87.

Schlee, E. "Eine unbekannte Anbetung der Hirten von Pieter Aertsen." Nordelbingen 12 (1936): $124-28$.

Serlio, Sebastiano. Het derde Boeck, Handelende van de aldervermaerste Antique edificien van Templen / Theatren / Amphitheatren / Paleysen / Thermen / Obelischen / Brugghen / Archen-triumphal / etc. Beschreven en gefigureert met haren gronden ende maten: ooc de plaetsen daer sestaen/ ende wiese dede maken. 1553.

Serlio, Sebastiano. Boek IV,Reglen van Metselrijen/op de vijve manieren van Edificien/te wetene/ Thuscana/Dorica/Ionica/Corinthia/en Composita: Ende daer by gesedt die exemplen vanden Antijquen/die in dmeeste deel met de leeringe van Vitruvio ouercommen. Met noch toeghesedtte figuren die int eerst niet en waren/ende sommige texten vanden Aucteur gebetert hier oock bij gesedt. Translated by Pieter Coecke van Aelst. 1549.

Siejek, Andreas. "Identifikation und Rekonstruktion graphischer Mittel auf dem Malgrund." 
In Die Unterzeichnung auf dem Malgrund. Graphische Mittel und Übertragungsverfahren im 15.-17. Jahrhundert, Andreas Siejek and Kathrin Kirsch, 13-143. Munich, 2004.

Tamis, Dorien. “The Genesis of Albert Cornelis' 'Coronation of the Virgin' in Bruges.” Burlington Magazine (November 2000): 672-80.

The Luminous Image: Painted Glass Roundels in the Lowlands, 1480-1560. Exh. cat. by Timothy Husband, et al. New York, The Metropolitan Museum of Art, 1995.

Verbraeken, Paul, ed. Joachim Beuckelaer: Het markt- en keukenstuk in de Nederlanden 15501650. Exh. cat. Ghent, Museum voor Schone Kunsten, 1986.

Wallen, Burr. "Jan van Hemessen, An Antwerp Painter between Reform and Counter-Reform." PhD diss., University of Michigan, 1976.

Wolters, Margreet. “Twee Kruisdragingen toegeschreven aan Joachim Beuckelaer: Infraroodreflectografisch onderzoek van de schilderijen te Älvkarleby en Hamburg." In Onverwacht bijeengebracht: Opstellen voor Ed Taverne en Lyckle de Vries ter gelegenheid van hun 25-jarig jubileum in dienst van de Rijksuniversiteit Groningen, edited by Jan L. de Jong and Elwin A. Koster, 149-57. Groningen, 1996.

Wolters, Margreet. “TwoVegetable Sellers by Joachim Beuckelaer: A Symbiotic Relationship." In Le dessin sous-jacent et la technologie dans la peinture, Colloque XV, Brugge, 11-13 septembre 2003 (La peinture ancienne et ses procédés: Copies, répliques, pastiches), edited by Hélène Verougstraete and Jacqueline Couvert, 159-67. Leuven, 2006.

Wolters, Margreet. “Creativity and Efficiency: Aspects of Joachim Beuckelaer's Use of Models and Patterns." Making and Marketing: Studies of the Painting Process in Fifteenth- and Sixteenth-Century Netherlandish Workshops, edited by Molly Faries, 155-78. Turnhout, 2006.

Wolters, Margreet, and Arie Wallert. “Joachim Beuckelaer, The Well-Stocked Kitchen.” In Still Lifes: Techniques and Style; An Examination of Paintings from the Rijksmuseum, exh. cat., edited by Arie Wallert, 40-43, cat. no. 1. Amsterdam, Rijksmuseum, 1999.

Wolters, Margreet. "'Met kool en crijt': De functie van de ondertekening in de schilderijen van Joachim Beuckelaer." PhD diss., Rijksuniversiteit Groningen, 2011.

\section{Recommended Citation:}

Margreet Wolters, "Drawing $\rightarrow$ Underdrawing $\rightarrow$ Painting: Compositional Evolution in the Working Process of Joachim Beuckelaer," JHNA 4:2 (Summer 2012), D0l:10.5092/jhna.2012.4.2.2 